\title{
Inter-ethnic relations of teenagers in England's schools: the role of school and neighbourhood ethnic composition
}

\author{
Simon Burgess and Lucinda Platt
}

\begin{abstract}
In the context of ongoing debate about the positive and negative consequences of ethnic diversity for intergroup relations, we study inter-ethnic relations among adolescents in England's schools. In the first national study of schools throughout England to relate inter-ethnic attitudes to both school and area ethnic composition, we combine survey data collected from 14-year-olds in nearly 100 schools with administrative data. We focus on relations between three ethno-racial categories: White British, Asian British and Black British, for three conceptually distinct indicators of interethnic orientations: warmth, friends, and attitudes. We posit that 'contact', proxied by school outgroup composition, should lead to more positive intergroup orientations, while 'exposure', proxied by neighbourhood outgroup composition, should lead to more negative intergroup relations. We show that higher school outgroup shares are associated with more positive orientations towards that group for almost all relationships and measures. We further show that for the two instances where higher school outgroup shares do not enhance positive intergroup orientations, they nevertheless moderate negative effects of neighbourhood composition. We conclude that schools offer the opportunity to enhance intergroup relations and to mitigate the threats associated with increased neighbourhood diversity with potentially enduring consequences.
\end{abstract}

\section{Introduction}

Harmonious intergroup relations are central to a well-functioning and cohesive society. Intergroup mistrust, animosity or avoidance can perpetuate inequalities and weaken social bonds. With growing shares of immigrant and minority ethnic and racial groups in Western societies (Alba and Foner 2015), the consequences of such diversity have garnered increasing 
academic attention (Putnam 2007). Ethnoracial diversity has been linked to both weaker social bonds (Alesina and La Ferrara 2000) and conflict and negative inter-group attitudes (Quillian 1995). But it has also been associated with greater inter-group empathy and reduced prejudice (Bowyer 2009; Sidanius et al. 2004; Van Laar et al. 2005; Oliver and Wong 2003). Studies exploring the consequences of more or less ethnically mixed schools and neighbourhoods on young people's attitudes have demonstrated similarly mixed findings (e.g. Bubritzki et al. 2018; Plenty and Jonsson 2017; Moody 2001; Kruse et al. 2016), and have revealed substantial cross-national variation (Janmaat 2014; McLaren 2003). This leaves open the question of whether the presence of those from other ethnic and racial groups fosters positive intergroup orientations among young people. Youth are a population of particular interest given greater potential malleability of their attitudes and the fact that they represent the population of the future.

We investigate the association of school and area composition with intergroup relations for a nationally representative sample of schoolchildren in England. We focus on three broad ethno-racial groups, well-recognised within the population and national categorisation: WhiteBritish, Asian-British and Black-British (ONS 2009). We locate our analysis within social identity theory (Tajfel 1982), contact theory (Allport 1954; Pettigrew 1998; Pettigrew and Tropp 2006), and theories of ethnic competition or threat (Bobo and Hutchings 1996). According to social identity theory, recognition of group difference is the precondition for hostility towards others (Tajfel 1982); but through contact it can lead to more positive attitudes (Pettigrew and Tropp 2006; McLaren 2003). However, exposure to others that is not accompanied by meaningful contact can result in feelings of threat (van de Meer and Tolsma 2014). Given that existing literature has tended to focus on a single dimension of interethnic relations with mixed results, we employ three conceptually distinct indicators of inter-ethnic relations: expressed warmth towards specific groups, friendship composition, and a more 
general attitudinal measure. We match survey data to administrative data on the ethno-racial composition of both the school and the area to assess two potentially contrasting influences on intergroup relations, characterised as 'contact' and 'exposure'.

Based on existing literature, we posit that schools provide settings with the potential to foster 'good contact', given increasing opportunities to interact with other groups. That is, as the numbers from outgroups increase, we expect increases in outgroup friendships, warmth and shifts in attitudes. Conversely, we situate neighbourhoods as sites of 'exposure', with more negative consequences for intergroup relations, except where moderated by school interaction.

To our knowledge, this is the first national study of schools throughout England to relate inter-ethnic orientations to both school and area composition. Since our measures of school and area composition derive from administrative data, they are independent of survey participation or respondents' perceptions. In our use of three conceptually distinct indicators of intergroup relations, we bring together discrete bodies of work focused on specific measures to provide a more general account. We also contribute to existing research by examining not only reciprocal orientations between majority and minorities, but additionally between minority groups. Our findings suggest that schools, rather than replicating segregation (Moody 2001; Thijs and Verkuyten 2014), facilitate more positive intergroup relations, and can mitigate negative consequences of neighbourhood composition.

\section{Literature and argument}

\section{Intergroup relations}

According to social identity theory (Tajfel 1982), people orient themselves in their behaviour towards others by recognition of group belonging. They tend to value those whom they recognise as part of their ingroup and develop negative behaviours or attitudes towards those constructed as outgroups. We start from the premise that race and ethnicity are widely 
recognised as bases of ingroup similarity (McPherson, Smith-Lovin and Cook 2001), but that own-group favouritism is somewhat malleable. An expanding literature charts how attitudes about, (preferences for) friendships with, and warmth towards those from other groups varies both individually (Stark, Mäs and Flache 2015) and with context (e.g. Janmaat 2014; Smith et al. 2016; Bubritzki et al. 2018). In particular, the literatures on contact and on threat highlight the role of context in both promoting and undermining positive intergroup relations (Bobo and Hutchings 1996; van de Meer and Tolsma 2014; Weber 2019).

Contact theory proposes that greater interaction between members of different groups can reduce relative preference for one's own group and promote positive responses both at the inter-individual level and towards the outgroup as a whole (Pettigrew and Tropp 2006). These benefits are, however, not guaranteed: contact can be negative as well as positive (Allport 1954). While 'good' contact leads to reciprocal understanding, undermining stereotypes, 'bad' contact leads to competition and conflict, and exclusionary attitudes (Pettigrew and Tropp 2006; Plenty and Jonsson 2017). Specifically, exposure to others without meaningful or positive contact can lead to mistrust, sense of 'threat' (Schneider 2008, Scheepers et al. 2002), and more negative outgroup orientations (Bowyer 2009).

Allport (1954) outlined four conditions conducive to positive consequences of contact for intergroup relations: groups' equal status in that context; common goals; need for intergroup cooperation; and an authority figure sanctioning cooperation. While subsequent literature suggests these conditions can be relaxed (Pettigrew and Tropp 2006; Pettigrew et al. 2011), they fit school students well (see also Bubritzki et al. 2018; Janmaat 2014; Smith et al. 2016).

The positive consequences of contact for intergroup relations have gained substantial empirical support in the social-psychological literature (Pettigrew 1998; Pettigrew and Tropp 2006; Pettigrew et al. 2011), supported by a range of observational studies (e.g. McLaren 2003; 
Schmid, Al Ramiah and Hewstone 2014), including studies of school contexts (e.g. Bubritzki et al. 2017; Janmaat 2014; Mikilikowska 2017). Yet, these findings are not universal. For example, Stark et al (2015) point to the ways in which positive outgroup attitudes are contingent on 'liking' the outgroup. Sidanius et al. (2004) illustrate patterns of within-campus 're-segregation' that foster negative attitudes in a diverse setting; and examining prejudice, Bowyer (2009) has shown concurrent evidence for both contact and conflict (see also Plenty and Jonsson 2017). Thijs and Verkuyten (2014) discuss the limits to ethnic diversity alone in driving positive interethnic relationships within schools; while Moody (2001) and Al Ramiah et al. (2015) describe how segregation and friendship homophily can increase with ethnic heterogeneity.

Studies that have focused on the composition of neighbourhoods have found more evidence for negative 'contact' and the role of competition. A substantial body of work has explored Putnam's (2007) contention that neighbourhood diversity reduces trust and other outcomes conceived as social capital/social cohesion (e.g. Alesina and La Ferrera 2000; Dinesen and Sønderskov 2015; Gijsberts, van der Meer and Dagevos, 2012; Laurence 2011). Results from these studies, though mixed, provide some support for the negative consequences of neighbourhood diversity. Quillian (1995) and Semyonov, Raijman and Gorodzeisky (2006) further find an association between the local share of minorities and anti-immigrant or prejudiced attitudes. Such findings have been explained in terms of theories both of competition and of cultural threat (Schneider 2008).

Consequences of area composition might also spill over into the school context, enhancing own-group preferences, even in contexts more conducive to 'good' contact. Weber (2019), for example, showed the sensitivity of majority groups' warmth towards outgroups to local conditions, while Mouw and Enwistle (2006) found that residential opportunity structures 
were reflected in school friendships. Conversely, Kruse et al. (2016) find that neighbourhood composition in the Netherlands did little to reduce within-school homophily.

\section{Causal studies}

The majority of this literature is observational and limited in demonstrating the causal impact of contact. A particular issue is that those who have more positive outgroup orientations may select into contexts with more outgroup contact (see e.g. Martinovic, van Tubergen and Maas 2009). Despite the challenge of allocating adults or children to different contact situations, some studies have managed to exploit experimental conditions to ascertain the causal impact of contact. While it is necessarily harder to generalise from the specific settings of these studies, they can inform our expectations. A positive influence of contact on attitudes to (marginalised) outgroups has been supported by random allocations in training camps for army conscripts in Norway (Finseraas et al. 2017), cricket teams in India (Lowe 2018), and among freshman on a US campus (Van Laar et al. 2005). Long-run positive effects of contact have been illustrated by Schindler and Westcott (2017) in a study of the allocation of black US army units across the UK during World War II. Positive effects on intergroup attitudes in schools specifically have been identified by Rao (2019), using a policy that required private schools in Delhi to take a quota of poor students. Rao (2019), like Van Laar et al. (2005), found that the effect extended beyond the particular group to more generally pro-social or less discriminatory attitudes.

Causal studies have also indicated the negative consequences for intergroup orientations of 'exposure', when considering experiences of: neighbourhood immigrant density without positive contact (Finseraas et al. 2017); minimal contact with Hispanics in a commuter setting (Enos 2014), and experience of refugee flows, again with limited direct contact 
(Hangartner et al. 2017). Lowe (2018) also showed that intergroup contact in a competitive rather than a collaborative context reduced friendships with outgroups.

These studies thus support expectations for distinct effects of contact and exposure, which may apply to our population of schoolchildren.

\section{Evaluating intergroup relations}

Existing studies differ in the concepts, and consequently the measures, they use to capture intergroup relations. While many focus on warmth towards others (often called "attitudes") (e.g. Bubritzki et al. 2018; Wölfer et al. 2018; Weber 2019), some consider more general views, such as anti-immigrant attitudes (e.g. Janmaat 2012, 2014; Miklikowska 2017), and others focus on friendships (e.g. Mouw and Entwistle 2006; Smith et al. 2016; Kruse et al. 2016). Both attitudes (warmth, views), and behaviours (friendships) speak to important elements of intergroup orientations. The advantage of conceptualising intergroup relations through attitudes is their potential to generalise more to other contexts (and groups); the advantage of focusing on friendship is that it is more directly connected to social relations, and demonstrates explicit behaviours. We therefore investigate three, conceptually distinct aspects of intergroup relations: warmth, friendships, and pro-minority attitudes.

The feeling thermometer (Nelson 2008) has a longstanding place in the measurement of responses towards different groups. Such measures of warmth are often employed as a single indicator in studies of contact on intergroup relations (e.g. Wölfer et al. 2016; Bubritzki et al. 2018; Weber 2019). We follow this literature in using warmth towards other groups as a key indicator of intergroup orientations. In line with existing literature, we anticipate that greater outgroup shares in school will increase warmth towards outgroups, through the conducive environment for positive contact effects (Allport 1954). By contrast we expect greater neighbourhood outgroup share, except when combined with higher school concentration, to be 
associated with lower warmth towards outgroups, given the feelings of mistrust or threat it may engender (cf. Schmid et al. 2014).

Our second measure is friendship composition. Friendships formed in adolescence can have important implications not only for adult friendships but also for future outgroup orientations (Merlino, Steinhardt and Wren-Lewis 2019). Friendship composition is the outcome of both preferences and opportunities. Opportunities are of course crucial. Even those most positively oriented towards another group will not be able to establish friends with them without the opportunities to do so. A number of studies have thus set out to capture friendship preferences adjusting for such differences in opportunities (e.g. Moody 2001; Smith et al. 2016). These have shed important light on within-group preferences, empirically supporting the argument that as minorities have greater opportunities to make friends within their group they do so, with rates of homophily higher among minorities than the majority.

Our aims and approach are somewhat different, since we are interested in the fuller friendship network that extends beyond the class, and even the school. Theoretically, contact effects should reach beyond the immediate context in which they arise (Pettigrew et al. 2011). To demonstrate 'positive contact', we might therefore expect more out-of-school as well as inschool friendships with outgroups, when outgroup shares in school increase. Neighbourhoods also constitute a set of opportunities for friendship (Mouw and Entwistle 2006). It is therefore important to be able to capture friendships based on area as well as those encountered in school to avoid underestimating neighbourhood influences on friendship composition. At the same time, since self-segregation mechanisms can prevent increasing outgroup shares from translating into more outgroup friends (Thijs and Verkuyten 2014; Moody 2001; Al Ramiah et al. 2015), we are interested in charting whether there is any absolute relationship between school composition and friendships. Overall, unlike with warmth, we would expect both neighbourhood and school opportunities to increase the probability of outgroup friendships, 
but that where schools foster outgroup friendships, this would enhance the extent to which students mix with outgroup friends outside school.

Our third indicator captures more general attitudes towards minorities. Though the classroom is an important context for shaping attitudes (Mitchell 2019; Mikilikowska 2017), attitudes to immigrants or minorities are conceptually distinct from other indicators of intergroup relations (Janmaat 2014). They are complementary to warmth and friendship as they can illustrate the extension of positive local relations to more general orientations. Attitudes formed in in the critical period of adolescence can form the basis of future world outlooks; yet evidence as to whether attitudes are promoted by diverse school contexts remains partial (Janmaat 2012). In line with most studies of general attitudes, we focus on attitudes to minorities / immigrants, which is therefore more informative about majority group orientations. Given the level of abstraction associated with attitudes, we expect them to be less sensitive to the proximity of more minority-group members at school, while being negatively associated with neighbourhood outgroup share (Quillian 2995; Semyonov et al. 2006). If they are found to be positively associated with school minority-group share, that would provide an important test for the contact hypothesis that positive contact translates to broader attitudes and orientations (cf. Rao 2019). By exploring all three indicators, consistent results can provide more robust support for our conclusions. In addition, because we expect these indicators to relate differently to school (proximate) and neighbourhood (more distant) influences, they may also shed further light on the processes at work.

\section{Asymmetry in expectations for intergroup relations}

We take away from the literature that, in a relatively controlled environment such as school, with clear sanctions against intolerant behaviour (Pettigrew 1998), positive consequences of contact on intergroup relations are likely to prevail. If this is the case, we should observe a 
positive 'contact' effect of increasing outgroup school share. We would expect this relationship to prevail for most indicators and group pairs. Nevertheless, there remains scope for asymmetries.

Asymmetry may arise from differences in group distributions within schools. WhiteBritish students rarely experience few own-group peers, by contrast with minorities in many schools. As a result, friendship selection might be more driven by school composition for minorities than for majority. We might, by contrast, expect positive responses from the majority to minorities to tail off at high levels of minority group concentration, either through competition processes or through the (re)segregation of minorities at increasing densities, which correspondingly reduces their friendships with majority peers (Moody 2001; Al Ramiah et al. 2015). There are, however, limits to such threshold effects in England, given that few majority students encounter more than 20 per cent of another group in their schools. Since opportunities for majority outgroup friendships are available to Black/Asian students in most schools, school composition may translate more weakly into minority-minority friendships.

At neighbourhood level, minorities are less likely to be sensitive to changes in majority group shares and consequent threat perceptions, since they are consistently aware of their national minority status. For the majority, higher local outgroup shares may lead to more negative orientations, consistent with existing literature, as context triggers anxiety or threat (Enos 2014; Quillian 1995; Schneider 2008). We anticipate such negative effects can be countered by greater levels of (good) contact (Pettigrew and Tropp 2006; McLaren 2003; Finseraas et al. 2017; Laurence 2011; Schmid et al. 2014). This leads us to expect school composition to moderate the effects of neighbourhood composition more for the majority.

Asymmetries also arise through differences in positions of dominance and corresponding psychological processes. Saguy et al (2009), for example, find that minorities tend to evaluate majority peers' pro-minority attitudes more positively than is justified; and 
Boda and Neray (2015) show that majorities are more negative to minorities than the reverse. Given minority-minority interactions are not part of dominant majority-minority relations, they might be less sensitive to context and more embedded in general stereotypes and hierarchies (Song 2004). Finally, research on the relationship between context and prejudiced or antiimmigrant attitudes focuses on majority views. It is unclear how strongly minorities will identify such attitudes with their own circumstances and, if they do, whether they would be sensitive to increasing majority-group school or neighbourhood shares.

\section{Data and measures}

Data

We use wave 1 of the England sample of the Children of Immigrants Longitudinal Survey in Four European Countries (CILS4EU) study (Kalter et al. 2017), which started in 2010/11. In England, state maintained schools stratified by their predicted proportion of minority group children were sampled using the National Pupil Database (NPD), discussed below. This ensured sufficient oversampling of schools with higher numbers of those of immigrant origin to facilitate analysis. A separate list enabled sampling of private schools. In each school two randomly selected classes of Year 10s (age 13-14) were invited to complete a self-completion questionnaire. By the end of fieldwork, a total sample of 96 state schools had supplied a sample of 3,958 children. Eleven private schools also responded, but are not included as they could not be matched to NPD data. Within-school response was around 80 per cent of eligible students.

To measure ethnic composition, we use the National Pupil Database (NPD), an administrative dataset compiled annually and covering all pupils in the state sector in England (93 per cent of all secondary school pupils). The dataset includes students' demographic data 
and exam scores. We obtained school identifiers to enable us to match aggregated NPD data at the school level.

\section{Variables}

\section{$\underline{\text { Dependent variables }}$}

Warmth: Our measure of 'warmth' is derived from a 'thermometer' (Nelson 2008) with a scale from 0-100 measuring feelings towards each of our ethno-racial groups of interest: Asian British, Black British or White British. To remove the influence of idiosyncratic responses to the thermometer question, we construct a measure that captures outgroup warmth net of warmth for one's own group. Since on average students feel greater warmth for their own group, this net warmth measure tends to be negative, though with variation across individuals and groups.

Friendship: Studies of homophily often exploit complete classroom network data to establish friendship preferences (e.g. Smith et al. 2016). This means, however, that they are constrained to only consider relationships within the classroom. Not all students have their closest or even any close friends within the specific class to which they are allocated. In England, a student's school class does not determine the subjects she takes or her ability grouping within core subjects. She will study different subjects with students from other classes. From examining data collected with the 'five best friends' instrument, which identifies key characteristics and patterns of contact with up to five selected friends, we observe that only one-third of these friends are actually in the respondent's class. This implies that classroombased sociometry analyses offer an important but partial account of friendships .

We therefore use a broader measure of outgroup friendship, derived from a question asking the share of friends from a White British, a Black or Black British background, an Asian or Asian British or any other background, with response options of 'Almost all or all', 'A lot', 
'About half', 'A few', 'None or very few' for each. We construct measures of the share of friends from the relevant outgroups, reverse-coded so that higher values represent a higher share. Since these shares are not absolute numbers, to a degree they are purged of differences in sociability. However, given the subjective nature and cognitive demands of the question, for robustness we supplement with the proportion of friends in the 'five best friends' data from each relevant outgroup.

Since these measures are necessarily confounded by within-school opportunities to make friends, we additionally measure whether students have an outgroup friend not in the school, identified using the 'five friends' data. Overall, about one in six friends are not in the school. In supplementary analysis, we also evaluate the probability of meeting an outgroup friend out of school.

Attitudes are derived from responses to two statements: "White British people should be open to the customs and traditions of ethnic minorities" and "Ethnic minority groups should do all they can to keep their customs and traditions". Responses are on a five-point scale from 'Strongly agree' to 'Strongly disagree'. We reverse coded and then averaged the responses to produce a measure of 'pro-minority' attitudes.

\section{$\underline{\text { Independent variables }}$}

Ethno-racial group. The official categorisation of ethnic groups in the UK is a pragmatic one intended to identify primarily 'visible' minorities (ONS 2009). The categories draw on a mixture of concepts, including colour and national origin, with limited reference to sociological concepts of ethnicity, but which serve administrative needs and have recognisability and acceptability within the population (Kertzer and Arel 2002; Burton, Nandi and Platt 2010; ONS 2009). Eighteen mutually exclusive ethnic group options in the official categorisation are organised into higher level categories of White, Asian/Asian British and Black/Black British, 
as well as Mixed or Multiple ethnic groups and Other ethnic groups. This official ethnic group question was asked in the second wave of the England CILS4EU survey. We therefore use responses from the second wave, which are available for 75 per cent of our sample, and focus on three broad groups - White-British (the first of the "White" categories, representing majority-group students) and the higher level Asian-British and Black-British categories. These categories match those in the questions on warmth and friends. We designate these categories ethno-racial groups, since their measurement reflects the ongoing relevance of race within the UK (Song 2018) as well as the conceptual and practical overlap between race and ethnicity (Umaña-Taylor et al. 2014).

Where we lack information on self-reported ethnic group, we use immigrant origins derived from data collected in the first wave (Dollmann, Jacob and Kalter 2014), which we modify with data from a question on what (minority) group respondents "feel they belong to". This allows us, for example, to allocate East Africans who regard themselves as 'Indian' (i.e. 'East African Asians') to the Asian category. We tested the robustness of our measure to minor modifications in how individuals were allocated to the ethno-racial categories, and the results were unaffected. Since those allocated to 'Other' form a heterogeneous group we exclude them from our analysis.

We derive measures of school and neighbourhood composition from the NPD. NPD ethnic group is based on self-report of the same official ethnic group categories that form the basis of our survey measure. We again focus on the higher level ethno-racial Asian-British and Black-British categories, alongside White-British, and calculate the school share of each of these groups over the five years that respondents had been in the school, i.e. 2007-2011. This not only smooths the data, avoiding potentially using data from an unrepresentative year, it also approximates the environment that the survey respondents experienced during their overall time in secondary school. Averages for any given year correlate highly with this overall mean. 
We note that school ethnic composition derived from the NPD, even for the specific survey year, differs slightly from the composition derived from the survey report of ethnicities in the classroom (Supplementary materials: Figure S1). This may suggest that survey response was higher for minorities and/or classes with more minority group students were allocated to the study, which was not part of the study design. Alongside the fact that students are taught and mix beyond their assigned 'class', analysis using survey-based classroom composition does not, therefore, fully reflect the students' context, further supporting use of external administrative data to evaluate school composition.

Given the sampling design, the composition of the schools in our sample does not reflect the distribution across schools in England as a whole. But, as illustrated in Table 1, the stratification of the sample results in a substantial range: from 0-40\% Asian-British, 0-25\% Black-British and 14-98\% White-British. In addition, the location of the schools is varied, covering both metropolitan, urban and rural areas.

[Table_1].

We use administrative local authority districts for our measure of neighbourhood composition. We again use five-year averages of ethno-racial group shares. In many places, these areas do not represent a small 'neighbourhood' but there are advantages and disadvantages of focusing too narrowly on small areas (Sharkey and Faber 2014).

To distinguish the effects of school and neighbourhood composition within the same analysis, we classify schools and neighbourhoods according to whether they have relatively high or relatively low shares of the outgroup, based on the median experience of each ethnic group. This gives us a four-way classification of neighbourhood and school ethno-racial group composition: Low-Neighbourhood-Low-School (reference), High-Neighbourhood-Low- 
School (which tests whether there is an effect of a high versus low neighbourhood relative to the reference category), Low-Neighbourhood-High-School, and High-Neighbourhood-HighSchool. We test whether the latter is significantly different from High-Neighbourhood-LowSchool to determine whether school moderates the impact of neighbourhood. This categorical measure offers a transparent way to test the different contributions of school and neighbourhood that is not sensitive to outliers. Alternative specifications provided consistent results.

\section{Control variables}

Previous research has suggested that more inclusive attitudes can be linked to educational level (Hjerm 2001). We therefore control for academic attainment using two measures of cognitive ability: sum scores from a language test and a cognitive skills test taken by study participants. Response to the parental questionnaire was low (around 36\%) and therefore did not provide an adequate measure of socio-economic background. Since child report of parents' education and socio-economic status is subject to considerable measurement error (Jerrim and Micklewright 2014), we used instead a measure of the number of books in the home reported by the student. This measure has been extensively used as proxy for the home environment (Marks, Cresswell and Ainley 2007), as well as an indicator of parental resources, and a standard proxy for socioeconomic status (Jerrim and Micklewright 2014; OECD 2016). We also adjust for sex of the pupil. Type of school did not add to the explanatory power of the model, so we excluded it. We do not report results for these control variables in our main tables, but all effects were in the expected directions: academic attainment and books in the home and being a girl were associated with more positive intergroup orientations.

Descriptives of dependent and independent variables by ethno-racial group are in the Supplementary Materials, Tables S1 and S2. 


\section{Analytical approach}

We explore the relationship between the share of the outgroup in school and neighbourhood and both warmth and friendships for each pair of White-British, Asian-British and BlackBritish respondents. For pro-minority attitudes, since these are not group specific, we simply explore the relationship with White-British share.

Our main results are based on linear regressions at pupil level, relating that individual's outgroup orientations to the composition of her school/neighbourhood, and her own characteristics. For the probability of having an out-of-school outgroup friend, we estimate a logit model. For friendship shares, for robustness we additionally estimated ordered logits with consistent results. We cluster standard errors at school-level to deal with within-school correlation of errors. Since, theoretically, we anticipated a possible non-linear relationship between school ethno-racial composition and intergroup relations, we evaluated different functional forms, testing for the optimal functional form using fractional polynomial regressions (Royston and Altman 1994) estimated using Stata's fpp command. In no instance did the estimates fail to reject the simple linear form as the optimal specification. On grounds of efficiency, as well as transparency, we therefore report the linear specification. It is worth noting that English schools in general are not highly segregated (see Table 1). Most variation in outgroup shares experienced by the majority White-British population is therefore at the bottom of the distribution, while minorities experience variation in White-British shares primarily towards the top of the distribution.

We adopt, however, a more flexible graphical analysis at the school level. We take school means of our measures, and plot these against school ethnic composition using LOWESS smoothers to summarise the general pattern. 


\section{Results}

We first present majority (White-British) to minority (Asian-British and Black-British) orientations; and then minorities towards majority, and towards each other. Results for each outcome for all pairs of intergroup relations are, however, reported in a single table. Within each subsection, for each dependent variable, we first examine the relationship with school composition both graphically at school level and in individual-level regressions, before turning to combined school and neighbourhood composition. For convenience, we summarise the results in Table 9.

\section{Majority towards Minorities}

The top panel of Figure 1 shows how White-British net warmth for both Asian-British and Black-British varies with the school share of those groups. However, when we estimate individual regressions (Table 2) we see that the relationship is only significant for warmth towards Black-British. That is, as the share of Black-British in the school increases, net warmth for this group also increases. This relationship is not observed for Asian-British. But when we combine school and neighbourhood composition (Table 6), we see that a higher neighbourhood concentration is associated with lower warmth towards Asian-British, and that this is significantly moderated by school composition (see test statistic). Thus, the absence of an association between school composition and warmth for Asian-British would appear to be a result of the two processes of (negative) exposure and (positive) contact cancelling each other out. Interestingly, we see from Table 6 that school composition also moderates neighbourhood composition for Black-British, though the negative effect of neighbourhood is not significant.

[Figure_1 Table_2 Table_6] 
Turning to friendships (Figure 2 and Table 3), as shares of Asian-British and BlackBritish increase in schools, White-British have more friends from these groups. (Ordered logits provide consistent results, as does outgroup share of 'five best friends': Supplementary Materials, Tables S3a,b). However, when estimating the probability of having an out-of-school outgroup friend, we see that this is significantly related to school composition for Black-British friends but not for Asian-British. When combined with the lack of school composition association with warmth (Table 2), this might indicate that friendships with Asian-British are shaped more by opportunities, and related less to the generalisability of outgroup orientations implied by contact theory. However, once again, when we look at area and school composition together (Table 7), we see that White friendships with Asians do not increase with neighbourhood share, unlike those with Black-British, but school composition significantly moderates this effect. This would seem to suggest that for White friendships with Asians negative consequences of 'exposure' outweigh opportunities at the neighbourhood level. The lack of neighbourhood (opportunity) effects might also explain why there are no 'contact' effects on out-of-school friendships. For friendships with Black-British, the opportunities of both neighbourhood and school seem to increase friendships, though to a much greater extent in school.

[Figure_2 Table_3 Table_7]

Finally, Figure 3 and Table 4 illustrate the positive relationship between a declining White-British share in the school and pro-minority attitudes. More minorities in school are associated with more positive pro-minority attitudes, but neighbourhood share does not have the same effect (lower panel of Table 4). 
[Figure_3 Table_4]

Overall, these results suggest that for the white majority, greater shares of minorities in their school lead to more positive orientations towards them on the different indicators; and that this school effect moderates more negative consequences of neighbourhood concentration of Asian-British.

\section{Minorities for Majority}

Figure 1 suggests a linear relationship between Asian-British and Black-British warmth towards White-British and share White-British in school; and this is supported by the individual level analysis in Table 2. It is worth noting that for Black and Asian respondents' net warmth approaches 0 (i.e. their feelings for the majority are the same as those for their own group) when they are in schools with 60 per cent or more white, which is the case for the majority of English schools (Table 1). This contrasts with the results for White-British respondents where net values remain negative at all distributions suggesting a somewhat asymmetric relationship. In line with expectations that minorities are less sensitive to variations in neighbourhood composition, more White-British in the neighbourhood is not significantly associated with warmth (Table 6). Nor is this moderated by school composition (the test statistic is not statistically significant).

Figure 2 and Table 3 show a clear association between the share of White-British in schools and minorities having a larger share of White-British friends. This is also found in the alternative specifications (Tables S3a-S3d). Black and Asian students' friendships with WhiteBritish are unaffected by neighbourhood composition (Table 7): opportunities at the neighbourhood level are not shaping friendship patterns. This makes it all the more striking 
that those in schools with higher shares of White-British students have a higher probability of having an out-of-school White-British friend. This offers a plausible indication that school composition represents positive 'contact', with wider effects on friendship networks. However, it is also possible that this finding reflects endogenous network processes (cf. Wimmer and Lewis 2010), whereby those with more White-British friends in school get to make friends with these White-British friends' out-of-school associates. This would imply that these out-ofschool friendships still derive from in-school contacts, rather than emerging independently. Nevertheless, it remains noteworthy that students choose to identify and spend time with such non-school-based outgroup friends.

We did not expect pro-minority attitudes of minorities to be sensitive to school (or neighbourhood) composition; and we see that while these attitudes are inversely associated with the share of White-British in the school, the associations are not statistically significant at conventional levels (Table 4).

\section{Minorities to Minorities}

While contact theory suggests we should see increasing positive orientations of Black-British and Asian-British to each other with higher school outgroup shares, existing literature offers little empirical guidance on this expectation. We find warmth of Black to Asian-British and Asian to Black-British is sensitive to school composition. While this association (though large) was not significant for Asian-British warmth for Black-British (Table 2), Table 6 shows that it significantly moderated a negative neighbourhood association. Comparable to White-British warmth for Asian-British, it would appear that greater 'exposure' results in more negative feelings of Asians for their Black peers, but that this is reversed with school 'contact'.

Asian-British have more Black friends the more there are in the school, but, unlike for Black students and their Asian friends, this does not extend to a higher probability of having 
an out-of-school Black-British friend. As for White-British friendships with Asian-British, this could point to the limits of school composition in translating opportunities beyond the school to more general orientations; but it could reinforce the conclusions from the neighbourhood analysis. That is, larger neighbourhood Black-British shares foster poorer Asian-Black intergroup relations, despite enhancing opportunities.

What is most striking, however, is the extent to which positive intergroup orientations do hold between minorities.

\section{Additional analysis}

We see a clear relationship between school composition and inter-group orientations. This association might, however, be generated by a causal mechanism, or by selection: that is, families with low (high) warmth towards other ethnic groups choosing (where possible) schools with a low (higher) fraction of 'outgroup' children. The data we have are observational, and the research design is not conducive to establishing causality.

However, to shed a little more light, we can focus on the process by which families are assigned to schools, and further exploit the NPD data. Parents make choices of schools, which, alongside school priorities, determine assignments. In choosing, parents evaluate different characteristics of schools. Given the importance of academic quality in parental decisions, lowperforming schools will tend be applied to by families who value other characteristics, including ethnic composition. Necessarily, therefore, fewer such families will apply to the higher-performing schools. If the relationship we have observed is all about selection, then in high-performing schools, with fewer families who highly value ethnic composition, the estimated correlation between composition and warmth should be much reduced. If the relationship is causal, then the estimates from only high-performing schools should echo our main findings. For three out of the four cases, the coefficients are very similar between the full 
and the high-performing school samples (Supplementary materials, Table S7). In the fourth case (Black-British for White-British) the coefficient is smaller, but this is also the instance with the smallest sample size.

We also note that in our estimates, even at low fractions of the 'outgroup', small increases make a difference. This fits well with the causal contact hypothesis: slightly more contact slightly increases warmth. It seems harder to reconcile that with a selection story, where we might expect to see more threshold effects. Together it seems unlikely that selection is the primary driver of our findings.

\section{Summary of results}

For convenience, given the range of analysis and results we summarise our findings in Table 9. Additionally, while we have conceived of warmth, friendship and pro-minority attitudes as conceptually distinct indicators of intergroup relations, in practice they do not occur independently. We therefore constructed a composite index from the three measures to capture the multidimensionality of attitudes and contacts (Eagly and Chaiken 2007; Thijs and Verkuyten 2014), and illustrate the overall implications of these interrelated mechanisms. We split responses on the index between those with a high and those with a low outgroup composite orientation. (For details on how we construct the measure, see Supplementary Materials.) Prominority attitudes cannot be construed as a measure of minority-minority relations so there is no composite measure for these relationships.

\section{[Table_9]}

Figure 4 plots high and low composite orientations against the school share of the outgroup, and illustrates their responsiveness to school composition. Table 5 shows that all associations are statistically significant, and non-negligible in size. For example, a $10 \%$ 
increase in the school share of Black-British is associated with a 9\% increase in the proportion of White-British students with high composite orientations towards Black-British. These composite orientations are largely insensitive to neighbourhood composition (Table 8), and tests of the difference between high-neighbourhood- low-school and high-neighbourhoodhigh-school are statistically significant in most cases. This suggests that, overall, school composition may both engender positive contact effects, and reduce negative intergroup orientations by moderating neighbourhood effects.

\section{[Figure_4 Table_5 Table_8]}

We can use this composite measure to illustrate the substantive potential of (changes in) school composition. Consider a hypothetical city with $20 \%$ Asian-British students and $80 \%$ White-British. A fully segregated system would imply that Asian-British students experience 0\% White-British students and White students experience 0\% Asian students. Using the more flexible estimates in Figure 4, approximately $47 \%$ of Whites would then have a low orientation towards Asian students and around 30\% of Asians would have a reciprocal low orientation; so overall $44 \%$ of all students in the city would be ill-disposed to the other group. By contrast, in a fully integrated system, only around $20 \%$ of students would have low orientations. In terms of high orientation, if this city's schools were fully segregated, only $18 \%$ would have high orientations to the other ethnic group, compared to $53 \%$ if fully integrated. Again, a very substantial difference.

\section{Conclusions}

In this paper, we extended existing literature on the role of school context in fostering positive or negative inter-ethnic relations. Given mixed existing evidence on context effects, we 
conceptualised two potential mechanisms of (positive) 'contact' on the one hand and 'exposure' on the other, which we proxied with measures of school and neighbourhood composition, derived from administrative data. Ours is the first British study to investigate the role of school and area composition on students' intergroup orientations for a national sample of schools.

Intergroup relations have been conceived and measured in various ways in the literature. We therefore used three complementary but conceptually distinct indicators: warmth, which has been used extensively in the contact literature, friendships, which have been extensively studied in school-based and homophily studies; and attitudes to minorities, which have featured more in the literature on competition and threat. We further enhanced existing literature by paying attention not only to reciprocal minority and majority relations but also those between minorities.

We found higher shares of outgroups in the school were in most cases associated with greater warmth towards and higher shares of friends from that group, and were positively associated with pro-minority attitudes of majority group students. By contrast we found few effects of neighbourhood composition on intergroup relations of schoolchildren. However, importantly, in the two cases where there was no positive effect of school-level outgroup concentration on intergroup relations, school composition nevertheless moderated a negative effect of neighbourhood composition.

We take from these findings a number of points. First, in the debate on whether schools act as sites of positive intergroup contact (e.g. Bubritzki et al. 2018) or of re-segregation (or victimisation) (e.g. Al Ramiah et al. 2015; Plenty and Jonsson 2017) our findings suggest that most of what happens in schools is 'good contact'. This is endorsed by the consistency across our different indicators. Encouragingly for policy-makers, our results indicate that even small changes in composition produce positive changes. Furthermore, despite limited existing 
research on the role of contact in enhancing inter-minority relations, we found that the effects were largely comparable between minorities.

Second, we identified a moderating influence of school on negative neighbourhood compositional effects in two cases where no school effect was observed. This demonstrates that even when schools appear not to have a positive effect on intergroup relations, we need to understand it in relation to the wider context: specifically, the potential for more negative orientations in the areas feeding schools. These negative associations with neighbourhood composition only applied to specific intergroup relations: White-British warmth for AsianBritish and Asian-British warmth for Black-British. This asymmetry suggests somewhat different underlying processes for different groups (cf. Bowyer 2009; Van Laar et al. 2005). It implies that particular stereotypes held by different groups shape how cultural threat or competition is experienced. For example, it has been argued that White-British perceive greater cultural distance for those of Asian origin (Ford 2011), which might prompt greater negativity as neighbourhood shares of Asian-British increase. For Asians, greater numbers of BlackBritish in the neighbourhood may trigger a greater sense of competition, and also invoke negative stereotypes of Black minorities in line with racial 'hierarchies' (Song 2004). Future research could valuably explore further the mechanisms underlying these distinctive patterns.

We observed a more general asymmetry in net warmth: the gap between minorities' warmth for their own group and for White-British was smaller than the gap between WhiteBritish own- and out-group warmth. For minorities, the gap was estimated to reduce to zero at levels of White-British found in the majority of the UK's schools, while for White-British it remained negative at all levels of out-group concentration. This may indicate the ambiguities highlighted by Saguy et al (2009), who find that contact can render minorities liable to overestimate the positive intergroup orientations of the majority. Contact effects may thus be particularly important for reshaping the intergroup orientations of the majority. 
There are clearly limits to our study, the interpretation of our findings is not straightforward, and we cannot claim to have identified a causal relationship. Selection is likely to play some role in what we observe; and clearly opportunities are important in the formation of friendships within school. Yet we presented indicative evidence that selection was not the whole story and that friendships were not simply driven by within-school constraints. Even if it is opportunities that shape friendship patterns, the consequences may still be substantively important for future group relations (Merlino et al. 2019).

This leads to our final conclusion. If more integrated schools offer sites for more positive intergroup relations, the policy question is then how to encourage mixed schools, and thence contact. This is not straightforward. Even within schools of a similar composition there was variation in students' interethnic orientations, indicating that what schools do also matters (Hjerm, Sevä and Werner 2018). Nevertheless, our paper offers some new evidence to support the development of policies that create opportunities for students from different backgrounds to mix, either in school, or outside. The value to researching and implementing policies to encourage contact is therefore clear. 


\section{References}

Alba, R. and Foner, N. 2015. Strangers No More. Immigration and the challenges of integration in North America and Western Europe. Princeton: Princeton University Press.

Alesina, A. and La Ferrara, E. 2000. "Participation in Heterogeneous Communities." The Quarterly Journal of Economics, 115(3):847-904.

Allport, G.W. 1954. The Nature of Prejudice. Cambridge, MA: Addison-Wesley.

Al Ramiah, A., Schmid, K., Hewstone, M., and Floe, C. 2015. “'Why Are All the White (Asian) Kids Sitting Together in the Cafeteria? Resegregation and the Role of Intergroup Attributions and Norms.” British Journal of Social Psychology, 54(1):100-124.

Bobo, L. and Hutchings, V.L. 1996. "Perceptions of Racial Group Competition: Extending Blumer's Theory of Group Position to a Multiracial Social Context." American Sociological Review, 61(6):951-972

Boda, Z. and Neray, B. 2015. "Inter-ethnic Friendship and Negative Ties in Secondary School." Social Networks, 43:57-72

Bowyer, B.T. 2009. “The Contextual Determinants of Whites' Racial Attitudes in England.” British Journal of Political Science, 39:559-586.

Bubritzki, S., van Tubergen, F., Weesie, J., and Smith, S. 2018. "Ethnic Composition of the School Class and Interethnic Attitudes: A Multi-Group Perspective.” Journal of Ethnic and Migration Studies 44(3):482-502.

Burton, J., Nandi, A., and Platt, L. 2010. "Measuring Ethnicity: Challenges and Opportunities for Survey Research.' Ethnic \& Racial Studies, 33(8):1332-1349

Dinesen, P.T., and Sønderskov, K.M. 2015. ’Ethnic Diversity and Social Trust: Evidence from the Micro-Context." American Sociological Review, 80(3):550-573. 
Dollmann, J., Jacob, K., and Kalter, F. 2014. Examining the Diversity of Youth in Europe. A Classification of Generations and Ethnic Origins Using CILS4EU Data (Technical Report). Mannheim: Mannheim Center for European Social Research.

Eagly, A.H., and Chaiken, S. 2007. "The Advantages of an Inclusive Definition of Attitude." Social Cognition, 25:582-602.

Enos, R.D. 2014. "Causal Effect of Intergroup Contact on Exclusionary Attitudes. PNAS, 111(10):3699-3704.

Ford, R. 2011. “Acceptable and Unacceptable Immigrants: How Opposition to Immigration in Britain is Affected by Migrants' Region of Origin.” Journal of Ethnic and Migration Studies, 37(7):1017-1037.

Finseraas, H., Hanson, T., Johnsen, A.A., Kotsadam, A. and Torsvik, G. 2017. Trust, Ethnic Diversity, and Personal Contact: Experimental Field Evidence. Oslo University Mimeo.

Gijsberts, M., Van der Meer, T., and Dagevos, J. 2012. “'Hunkering Down' in Multi-Ethnic Neighbourhoods? The Effects of Ethnic Diversity on Dimensions of Social Cohesion." European Sociological Review, 28(4):527-37.

Hangartner, D., Dinas, E., Marbach, M., Matakos, K and Xefteris, D. (2017). Does Exposure to the Refugee Crisis Make Natives More Hostile? IPL Working Paper 17-02.

Hjerm, M. 2001. "Education, Xenophobia and Nationalism: A Comparative Analysis,", Journal of Ethnic and Migration Studies, 27(1):37-60.

Hjerm, M. Sevä, I.J., and Werner, L. 2018. "How Critical Thinking, Multicultural Education and Teacher Qualification Affect Anti-immigrant Attitudes." International Studies in Sociology of Education, 27(1):42-59.

Janmaat, J.G. 2012. "The Effect of Classroom Diversity on Tolerance and Participation in England, Sweden and Germany." Journal of Ethnic and Migration Studies, 38(1):2139. 
Janmaat, J.G. 2014. "Do Ethnically Mixed Classrooms Promote Inclusive Attitudes Towards Immigrants Everywhere? A Study Among Native Adolescents in 14 Countries." European Sociological Review 30(6):810-822.

Jerrim, J., and Micklewright, J. 2014. “Socio-economic Gradients in Children's Cognitive Skills: Are Cross-Country Comparisons Robust to Who Reports Family Background?" European Sociological Review 30(6):766-781.

Kalter, F., Heath, A.F., Hewstone, M., Jonsson, J.O., Kalmijn, M., Kogan, I., van Tubergen, F. 2017. Children of Immigrants Longitudinal Survey in Four European Countries (CILS4EU) GESIS Datenarchiv, Köln. ZA5656 Datenfile Version 3.3.0.

Kertzer, D.I. and Arel, D. (eds.) 2002. Census and Identity: The Politics of Race, Ethnicity, and Language in National Censuses. Cambridge: Cambridge University Press.

Kruse, H., Smith, S., van Tubergen, F., Maas, I. 2016. "From Neighbors to School Friends? How Adolescents' Place of Residence Relates to Same-ethnic School Friendships.” Social Networks, 44:130-142.

Laurence, J. (2011). "The Effect of Ethnic Diversity and Community Disadvantage on Social Cohesion: A Multi-level Analysis of Social Capital and Interethnic Relations in UK Communities.” European Sociological Review, 27(1):70-89.

Lowe, M. 2018. Types of Contact: A Field Experiment on Collaborative and Adversarial Caste Integration. Job Market Paper, 18 January.

Marks, G.N., Cresswell, J. and Ainley, J. 2007. "Explaining Socioeconomic Inequalities in Student Achievement: The Role of Home and School Factors." Educational Research and Evaluation, 12(2):105-128.

McLaren, L.M. 2003. “Anti-immigrant Prejudice in Europe: Contact, Threat Perception, and Preferences for the Exclusion of Migrants." Social Forces 81(3):909-936. 
McPherson, M. Smith-Lovin, L. and Cook, J.M. 2001. "Birds of a Feather: Homophily in Social Networks. Annual Review of Sociology, 27:415-44.

Martinovic, B. van Tubergen, F. and Maas, I. 2009. "Dynamics of Interethnic Contact: A Panel Study of Immigrants in the Netherlands." European Sociological Review, 25(3):303318.

Merlino, L.P., Steinhardt, M.F. and Wren-Lewis, L. 2019. "More than Just Friends? School Peers and Adult Interracial Relationships.” Journal of Labor Economics, 37(3):663713.

Miklikowska, M. 2017. "Development of Anti-immigrant Attitudes in Adolescence: The Role of Parents, Peers, Intergroup Friendships, and Empathy." British Journal of Psychology, 108:626-648.

Mitchell, J. 2019. "Prejudice in the Classroom: A Longitudinal Analysis of Anti-Immigrant Attitudes.” Ethnic and Racial Studies, 42(9):1514-1533.

Moody, J. (2001). "Race, School Integration, and Friendship Segregation in America." American Journal of Sociology, 107(3):679-716.

Mouw. T., and Entwistle B. 2006. "Residential Segregation and Interracial Friendship in Schools.” American Journal of Sociology, 111(2):394-441.

Nelson, S.C. 2008. "Feeling Thermometer" in P.J. Lavrakas (ed.) Encyclopedia of Survey Research Methods. London: Sage.

OECD. 2016. PISA 2015 Results (Volume One): Excellence and Equity in Education. Paris: OECD.

Office for National Statistics [ONS] 2009. Final Recommended Questions for the 2011 Census in England and Wales Ethnic Group. London: ONS.

Oliver, J.E. and Wong, J. 2003. "Intergroup Prejudice in Multiethnic Settings.” American Journal of Political Science, 47:567-582. 
Pettigrew, T.F. 1998. “Intergroup Contact Theory.” Annual Review of Psychology, 49:65-85.

Pettigrew, T.F., and Tropp, L.R. 2006. “A Meta-Analytic Test of Intergroup Contact Theory.” Journal of Personality and Social Psychology, 90(5):751-783.

Pettigrew, T.F., Tropp, L.R., Wagner, U., and Christ, O. 2011. "Recent Advances in Intergroup Contact Theory." International Journal of Intercultural Relations, 35(3):271-280.

Plenty, S., and Jonsson, J.O. 2017. "Social Exclusion Among Peers: The role of Immigrant Status and Classroom Immigrant Density." Journal of Youth and Adolescence, 46(6):1275-1288.

Putnam, R.D. 2007. "E Pluribus Unum: Diversity and Community in the Twenty-first Century. The 2006 Johan Skytte Prize Lecture.” Scandinavian Political Studies, 30:137-174.

Quillian, L. 1995. "Prejudice as a Response to Perceived Group Threat: Population Composition and Anti-immigrant and Racial Prejudice in Europe." American Sociological Review 60(4):586-611.

Rao, G. 2019. "Familiarity Does Not Breed Contempt: Generosity, Discrimination, and Diversity in Delhi Schools.” American Economic Review, 109(3):774-809.

Royston, P., and Altman, D.G. 1994. "Regression Using Fractional Polynomials of Continuous Covariates: Parsimonious Parametric Modelling." Journal of the Royal Statistical Society. Series C (Applied Statistics), 43(3):429-467.

Saguy, T., Tausch, N., Dovidio, J.F. and Pratto, F. 2009. “The Irony of Harmony: Intergroup Contact Can Produce False Expectations for Equality." Psychological Science, 20(1):114-121.

Scheepers, P., Gijsberts, M., and Coenders, M. 2002. "Ethnic Exclusionism in European Countries: Public Opposition to Civil Rights for Legal Migrants as a Response to Perceived Ethnic Threat.” European Sociological Review 18(1):17-34. 
Schindler, D., and Westcott, M. 2017. "Shocking Racial Attitudes: Black G.I.s in Europe." CESifo Working Papers 6723.

Schmid, K., Al Ramiah, A., and Hewstone, M. 2014. "Neighborhood Ethnic Diversity and Trust: The Role of Intergroup Contact and Perceived Threat.” Psychological Science, 25(3):665-674.

Schneider, S.L. 2008. "Anti-immigrant Attitudes in Europe: Outgroup Size and Perceived Ethnic Threat." European Sociological Review, 24(1):53-67

Semyonov, M., Raijman, R., and Gorodzeisky, A. 2006. “The Rise of Antiforeigner Sentiment in European Societies.” American Sociological Review, 71(3): 426-49.

Sharkey, P., and Faber, J.W. 2014. "Where, When, Why, and For Whom Do Residential Contexts Matter? Moving Away from the Dichotomous Understanding of Neighborhood Effects.” Annual Review of Sociology, 40(1):559-579.

Sidanius, J., Van Laar, C., Levin, S., and Sinclair, S. 2004. "Ethnic Enclaves on the College Campus: The Good, the Bad and the Ugly." Journal of Personality and Social Psychology, 87:96-110.

Smith, S., McFarland, D.A., Van Tubergen, F., and Maas, I. 2016. "Ethnic Composition and Friendship Segregation: Differential Effects for Adolescent Natives and Immigrants." American Journal of Sociology, 121(4):1223-1272.

Song, M. 2004. "Introduction: Who's at the Bottom? Examining Claims about Racial Hierarchy." Ethnic and Racial Studies, 27(6):859-877.

Song, M. 2018. "Why We Still Need to Talk about Race." Ethnic and Racial Studies, 41(6):1131-1145.

Stark, T.H., Mäs, M., and Flache, A. 2015. "Liking and Disliking Minority-Group Classmates: Explaining the Mixed Findings for the Influence of Ethnic Classroom Composition on Interethnic Attitudes." Social Science Research 50:164-176. 
Tajfel, H. (1982). “Social Psychology of Intergroup Relations.” Annual Review of Psychology, 33:1-39.

Thijs, J., and Verkuyten, M. 2014. "School Ethnic Diversity and Students' Interethnic Relations.” British Journal of Educational Psychology, 84(1):1-21.

Umaña-Taylor, A.J., Quintana, S.M., Lee, R.M., Cross, W.E., Jr, Rivas-Drake, D., Schwartz, S.J. et al. 2014. "Ethnic and Racial Identity during Adolescence and into Young Adulthood: An Integrated Conceptualization." Child Development, 85(1):21-39.

van de Meer, T., and Tolsma, J. 2014. "Ethnic Diversity and its Effects on Social Cohesion." Annual Review of Sociology, 40:459-78.

Van Laar, C., Levin, S. Sinclair, S., and Sidanius, J. 2005. “The Effect of University Roommate Contact on Ethnic Attitudes and Behavior." Journal of Experimental Social Psychology, 41(4):329-45.

Weber, H. 2019. “Attitudes Towards Minorities in Times of High Immigration: A Panel Study among Young Adults in Germany.” European Sociological Review, 35(2):239-257.

Wimmer, A., and Lewis, K. 2010. "Beyond and Below Racial Homophily: ERG Models of a Friendship Network Documented on Facebook." American Journal of Sociology, 116(2):583-642. 
Inter-ethnic relations: Figures and Tables: FIGURES

Figure 1: LOWESS of net warmth for outgroup by ethnic composition of school, by ethno-racial group, school level

Mean White British net warmth for Asian, by \% Mean White British net warmth for Black, by \% Asian British in school Black British in school

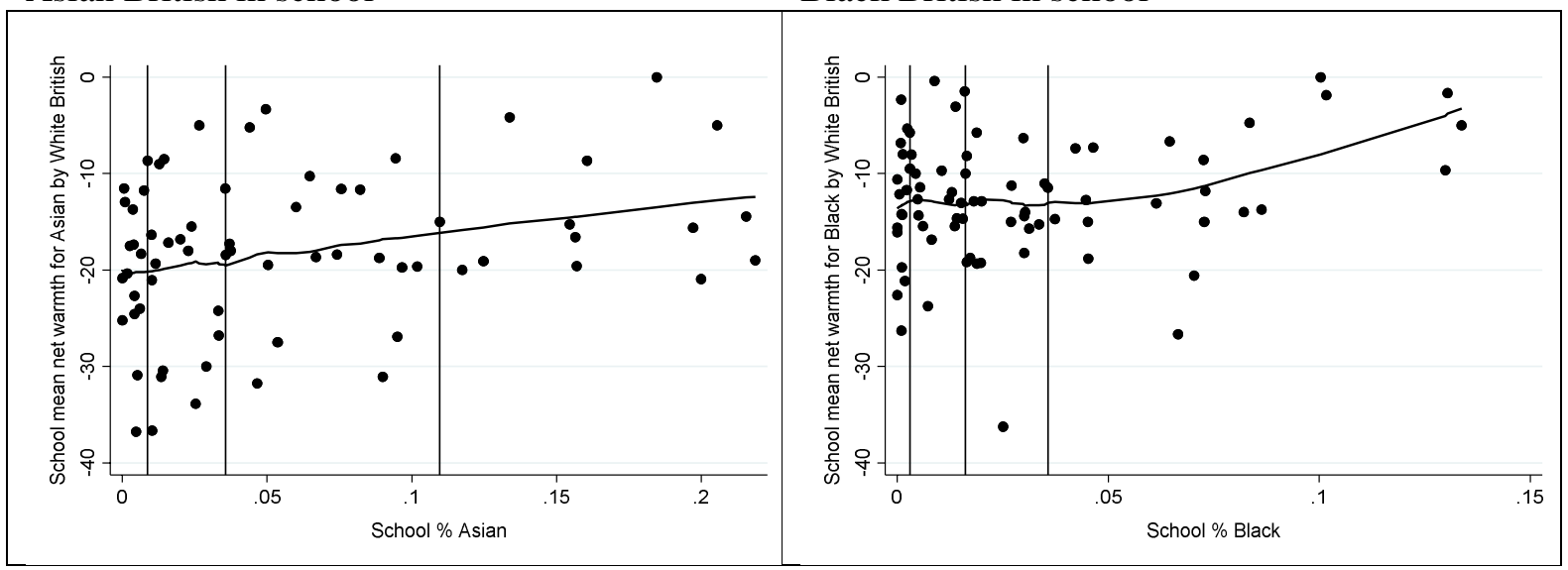

Mean Asian British net warmth for White, by \% Mean Black British net warmth for White, by \% White British in school

White British in school

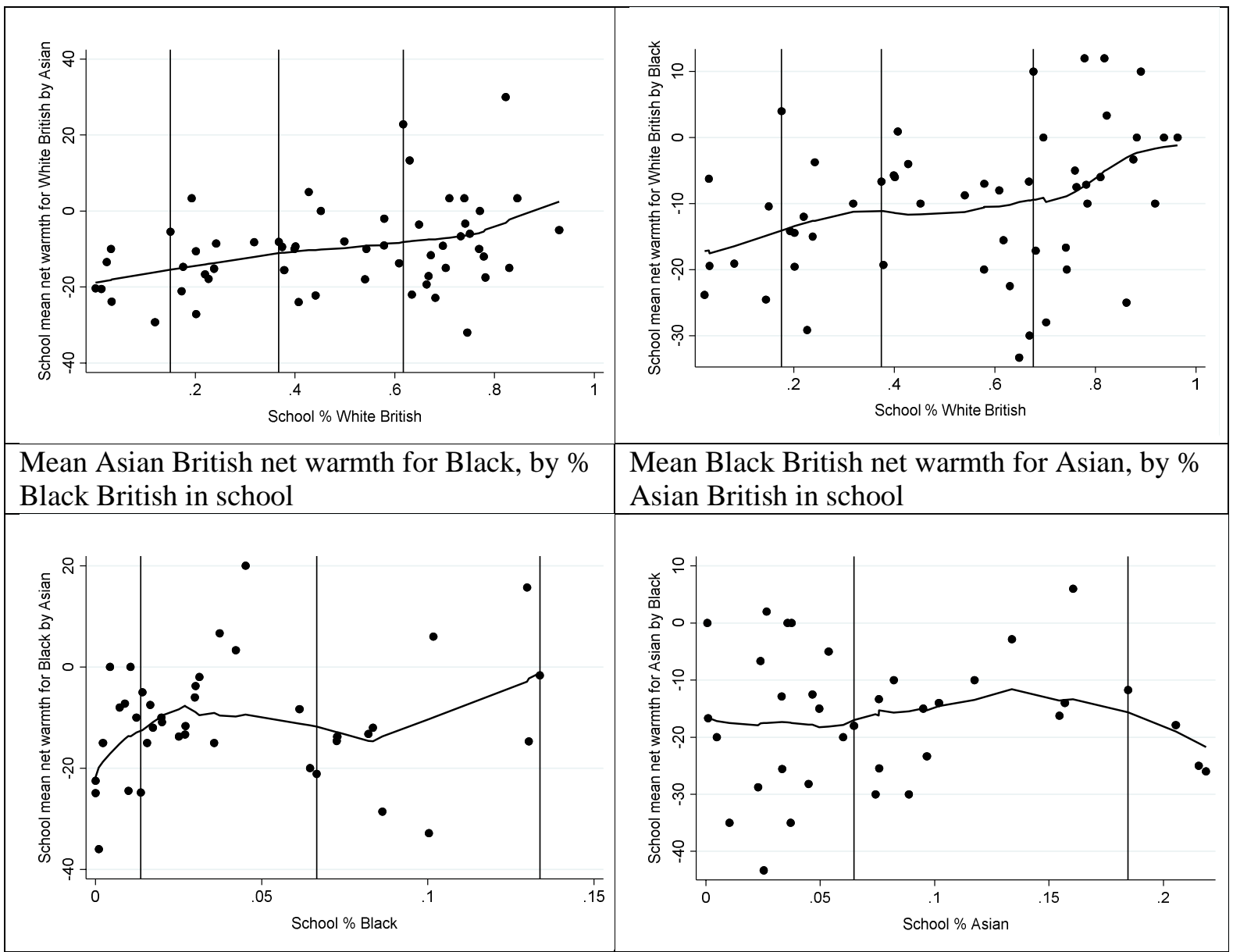

Source: CILS4EU, UK Sample, Wave $1 \&$ NPD. Note: vertical lines at lower and upper quartiles and median of school composition. For clarity, X-axis range is up to $90^{\text {th }}$ percentile of national distribution. Figures showing the full distribution are supplied in the online Supplementary materials. 
Figure 2: LOWESS of share of outgroup friends by ethnic composition of school, by ethnoracial group, school level

Share of Asian friends of White British, by \% Share of Black British friends of White British, Asian British in school by $\%$ Black British in school
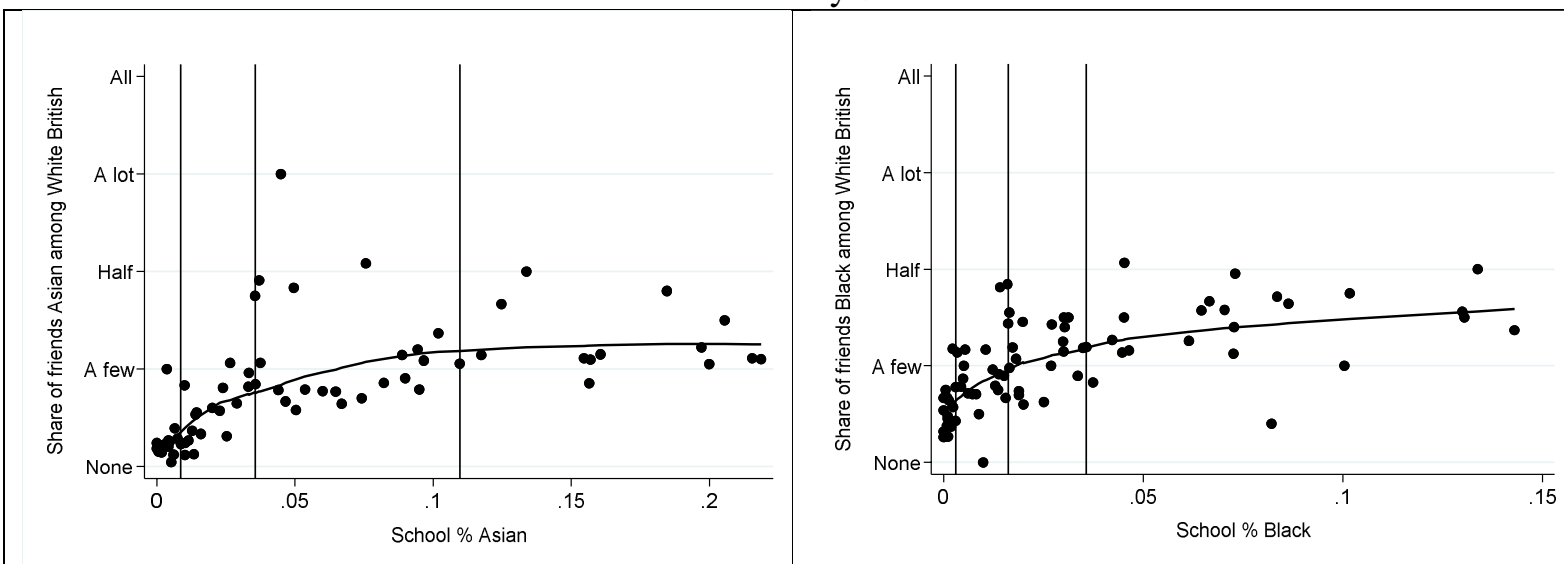

Share of White friends of Asian British, by \% White British in school

Share of White friends of Black British, by \%

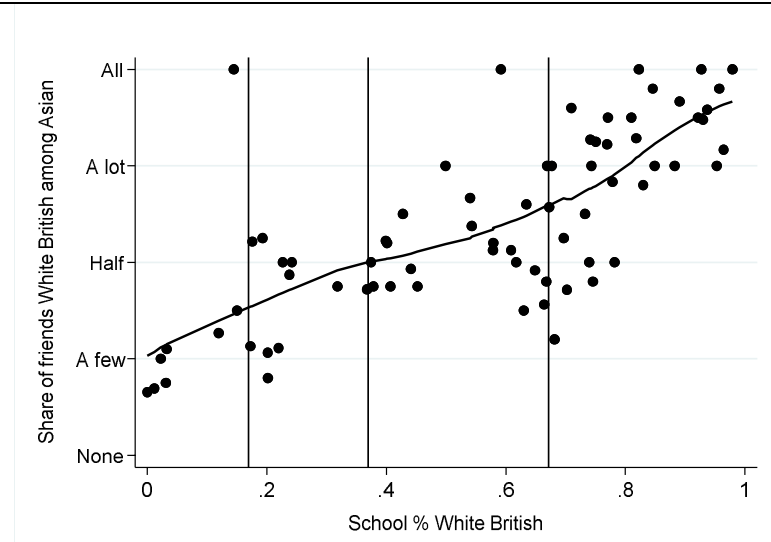

White British in school

Share of Black friends of Asian British, by \% Black British in school

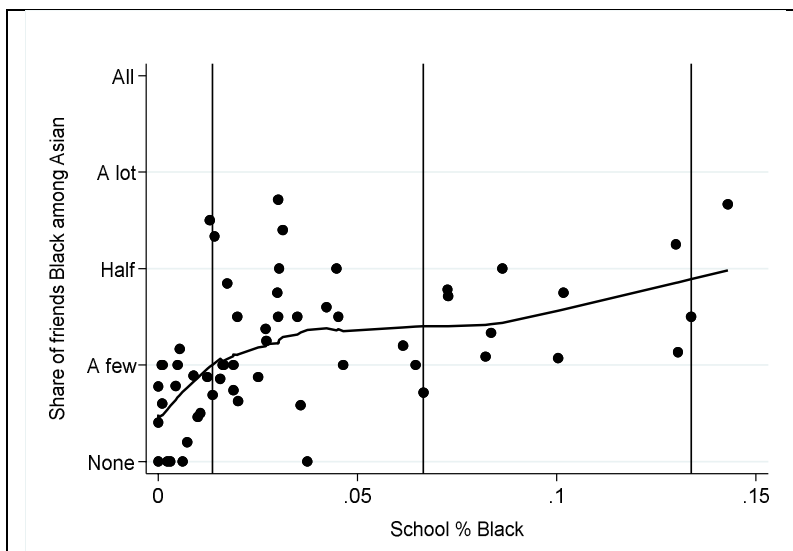

Share of Asian friends of Black British, by \% Asian British in school

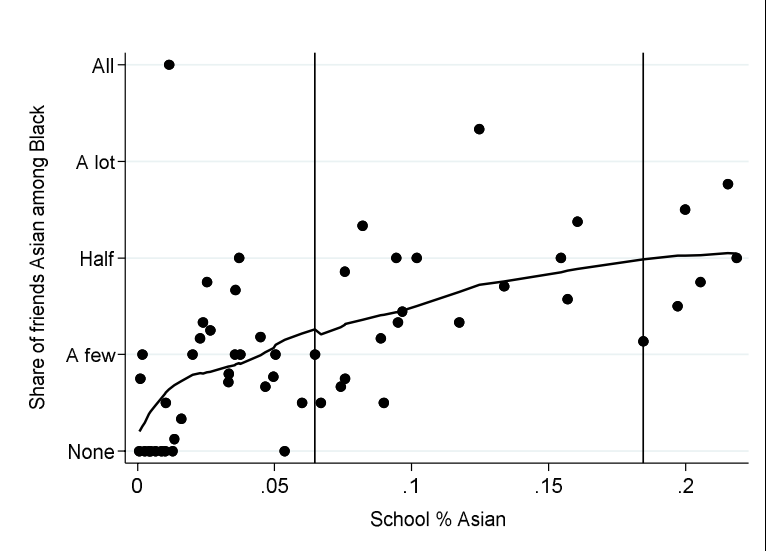

Source: CILS4EU, UK Sample, Wave 1 \& NPD. Note: vertical lines at lower and upper quartiles and median of school composition as experienced by individuals from each group. For clarity, X-axis range is up to $90^{\text {th }}$ percentile of national distribution. Figures showing the full distribution are supplied in the online Supplementary materials. 
Figure 3: LOWESS of pro minority attitudes by \% White British in school, by ethno-racial group, school level

White British pro minority attitudes by share White British in school

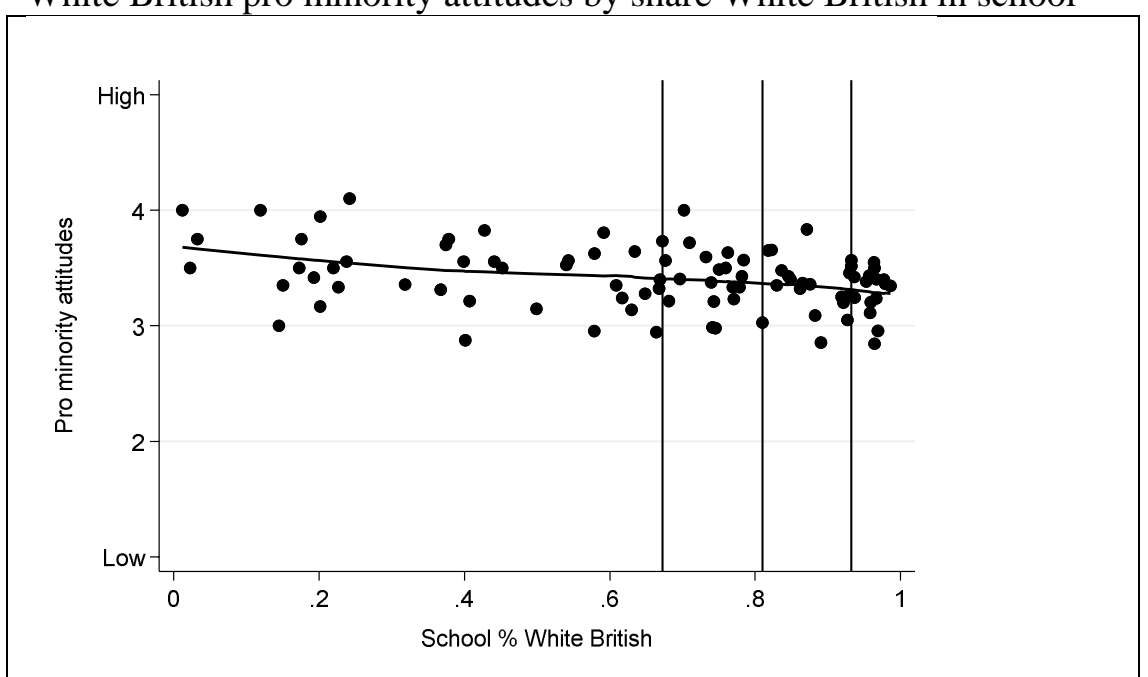

Asian British pro minority attitudes by $\%$ White British in school

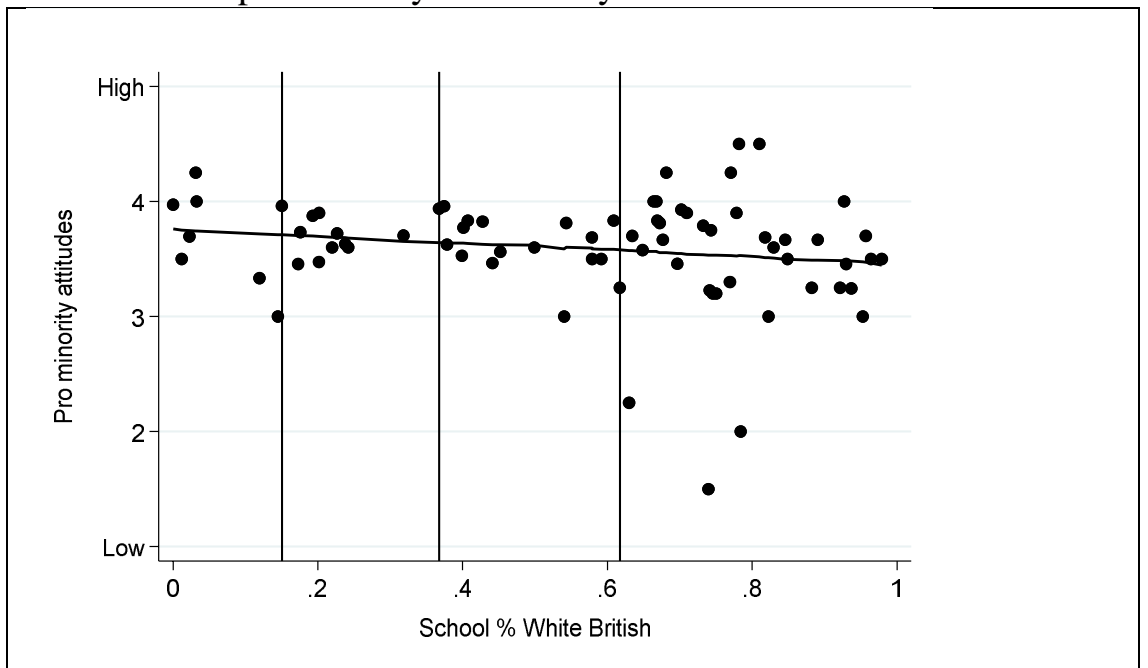

Black British pro minority attitudes by $\%$ White British in school

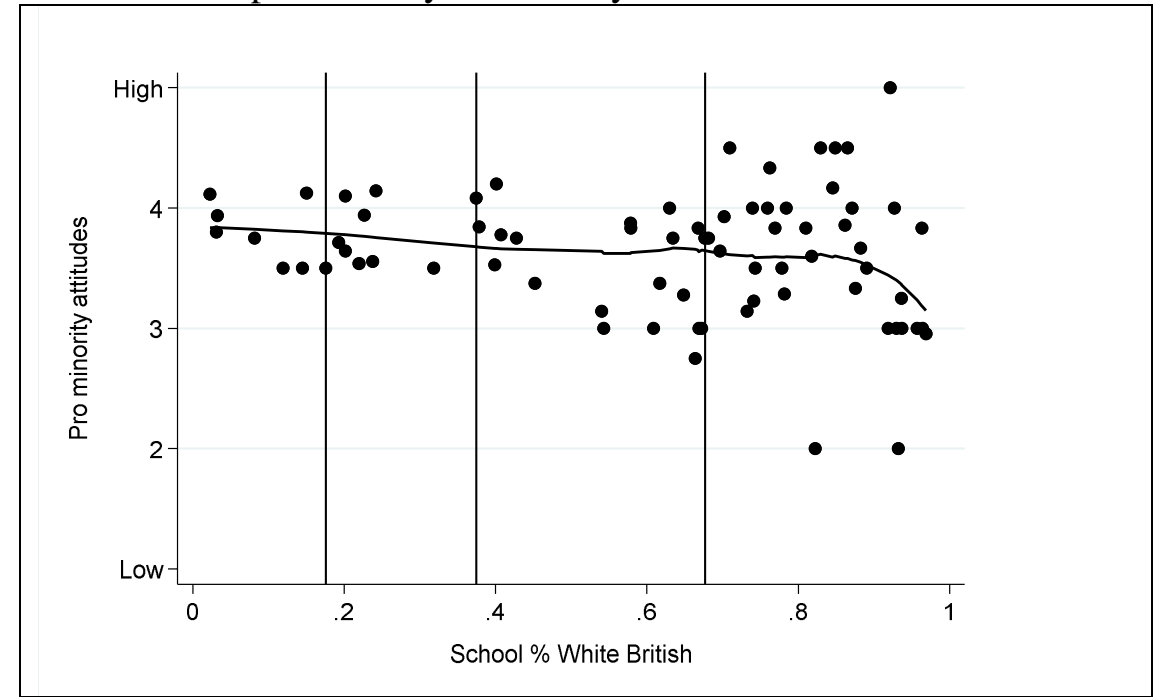

Source: CILS4EU, UK Sample, Wave 1 \& NPD. Note: vertical lines at lower and upper quartiles and median of school composition as experienced by individuals from each group. 
Figure 4: LOWESS of high and low composite orientation towards outgroup by ethnic composition of school, by ethnic group, school level

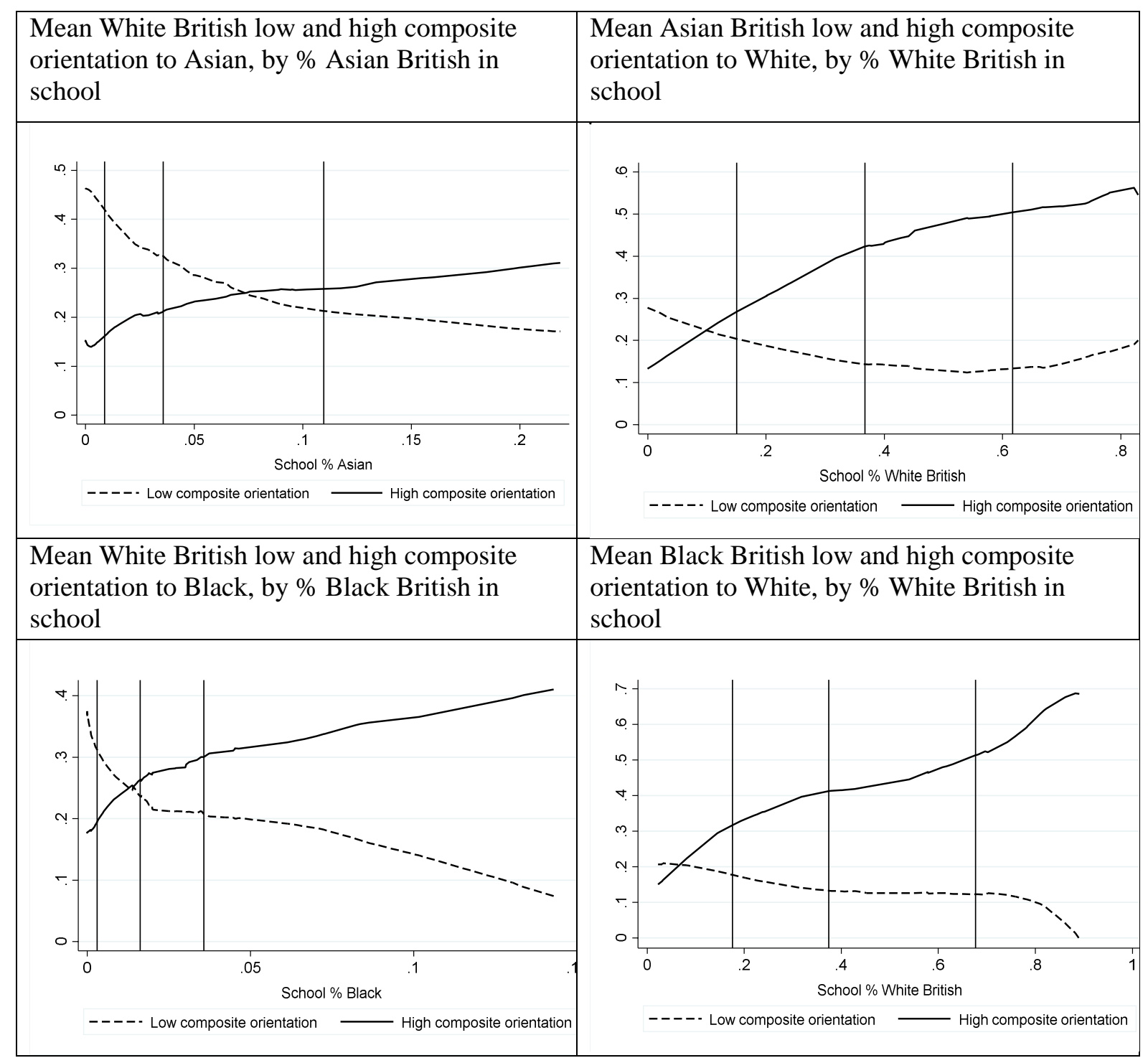

Source: CILS4EU, UK Sample, Wave 1 \& NPD. Note: Vertical lines at lower and upper quartile and median. $\mathrm{X}$-axis range is up to $90^{\text {th }}$ percentile of national distribution 
Tables

Table 1: Ethno-racial composition of schools in England and in sample

\begin{tabular}{lrrrrrr}
\hline & \multicolumn{3}{c}{ CILS4EU sample } & \multicolumn{3}{c}{ National Sample } \\
& $\begin{array}{r}\text { Asian } \\
\text { British }\end{array}$ & $\begin{array}{r}\text { Black } \\
\text { British }\end{array}$ & $\begin{array}{r}\text { White } \\
\text { British }\end{array}$ & $\begin{array}{r}\text { Asian } \\
\text { British }\end{array}$ & $\begin{array}{r}\text { Black } \\
\text { British }\end{array}$ & $\begin{array}{r}\text { White } \\
\text { British }\end{array}$ \\
\hline Mean & 15.9 & 8.0 & 67.9 & 8.0 & 4.5 & 78.2 \\
SD & 20.3 & 12.6 & 28.5 & 15.4 & 9.9 & 26.0 \\
Percentiles & & & & & & \\
p5 & 0.2 & 0 & 12.3 & 0 & 0 & 13.7 \\
p10 & 0.4 & 0.1 & 22.4 & 0 & 0 & 32.3 \\
p25 & 1.5 & 0.7 & 45.7 & 0.6 & 0 & 73.6 \\
p50 & 7.6 & 2.7 & 78.3 & 2 & 0.7 & 89.5 \\
p75 & 23.3 & 8.5 & 91.5 & 7.3 & 3.5 & 95.1 \\
p90 & 45.0 & 21.4 & 96.9 & 21.9 & 13.8 & 97.5 \\
p95 & 58.7 & 42.4 & 97.8 & 40.2 & 25.4 & 98.4 \\
\hline S0ury
\end{tabular}

Source: NPD matched to CILS4EU, columns 1-3; NPD, columns 4-6.

Table 2: OLS regression of association between school composition and net warmth towards other ethno-racial groups by ethno-racial group, individual level with controls

\begin{tabular}{|c|c|c|c|c|c|c|}
\hline & $\begin{array}{c}\text { Net } \\
\text { warmth: } \\
\text { White for } \\
\text { Asian }\end{array}$ & $\begin{array}{c}\text { Net } \\
\text { warmth: } \\
\text { White for } \\
\text { Black }\end{array}$ & $\begin{array}{c}\text { Net } \\
\text { warmth: } \\
\text { Asian for } \\
\text { White }\end{array}$ & $\begin{array}{c}\text { Net } \\
\text { warmth: } \\
\text { Black for } \\
\text { White }\end{array}$ & $\begin{array}{c}\text { Net } \\
\text { warmth: } \\
\text { Asian for } \\
\text { Black }\end{array}$ & $\begin{array}{c}\text { Net } \\
\text { warmth: } \\
\text { Black for } \\
\text { Asian }\end{array}$ \\
\hline School \% & -2.69 & & & & & $14.11 *$ \\
\hline Asian & (7.28) & & & & & $(6.92)$ \\
\hline School \% & & $17.87 *$ & & & 10.76 & \\
\hline Black & & $(7.07)$ & & & $(9.79)$ & \\
\hline School \% & & & $14.23 * * *$ & $13.58 * *$ & & \\
\hline White British & & & $(4.07)$ & $(4.97)$ & & \\
\hline Personal Chars & Yes & Yes & Yes & Yes & Yes & Yes \\
\hline$R^{2}$ & 0.06 & 0.04 & 0.06 & 0.05 & 0.06 & 0.04 \\
\hline Observations & 1959 & 1964 & 619 & 374 & 616 & 372 \\
\hline
\end{tabular}

Source: CILS4EU, UK Sample, Wave $1 \&$ NPD. Notes: Standard errors in parentheses. Standard errors clustered at school level. Personal characteristics comprise: sex, number of books in the home, language test score, cognitive test score.

$+\mathrm{p}<0.10, * \mathrm{p}<0.05, * * \mathrm{p}<0.01, * * * \mathrm{p}<0.01$ 
Table 3: OLS regression of association between school composition and share of friends from other ethno-racial groups by ethno-racial group, individual level with controls

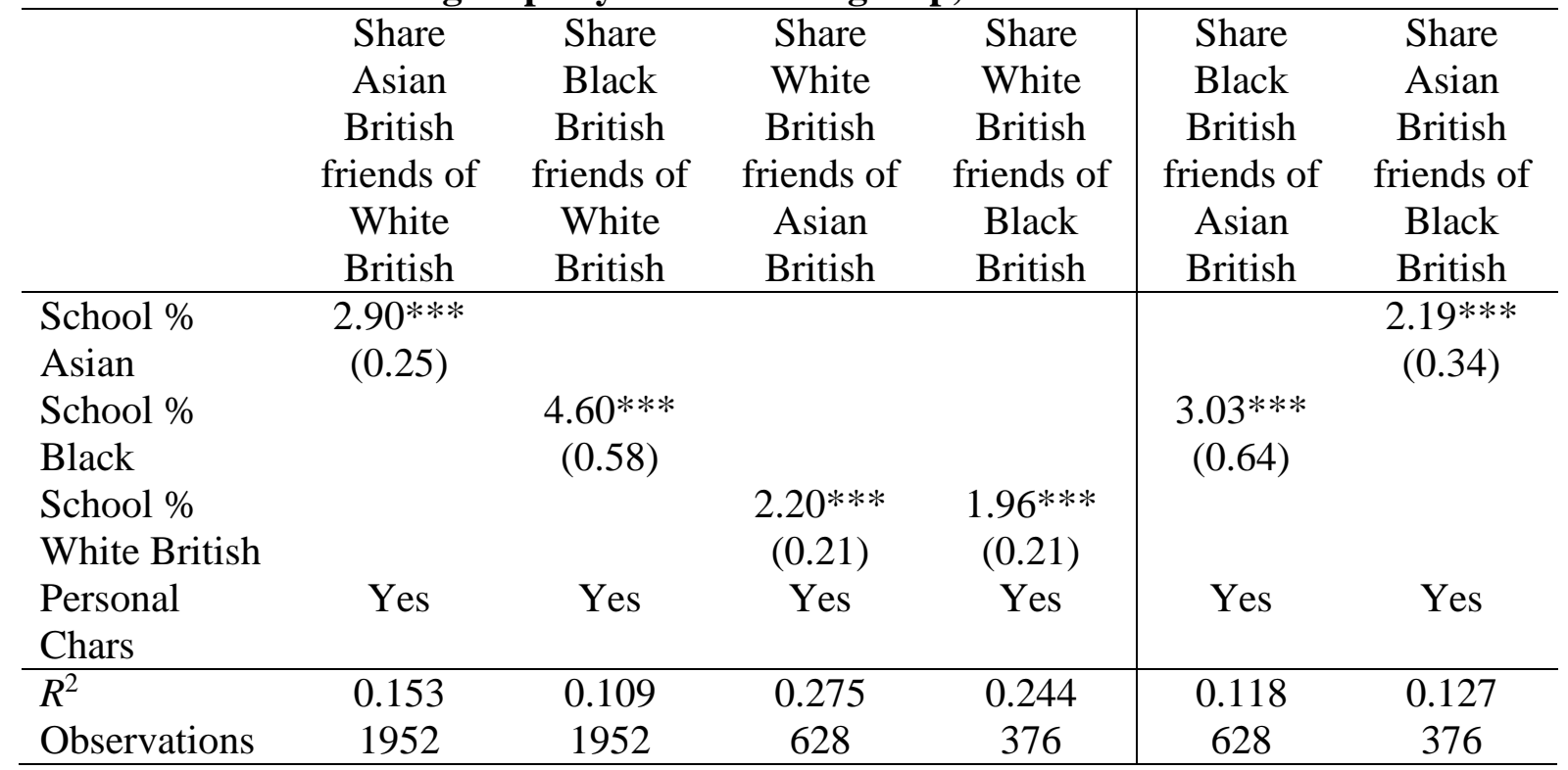

Source: CILS4EU, UK Sample, Wave 1 \& NPD. Notes: Standard errors in parentheses. Standard errors clustered at school level. Personal characteristics comprise: sex, number of books in the home, language test score, cognitive test score.

$+\mathrm{p}<0.10, * \mathrm{p}<0.05, * * * \mathrm{p}<0.01, * * * \mathrm{p}<0.001$

Table 4: OLS regression of association between school composition and pro-minority attitudes, by ethno-racial group, individual level with controls

\begin{tabular}{|c|c|c|c|}
\hline & $\begin{array}{l}\text { White British pro } \\
\text { minority attitudes }\end{array}$ & $\begin{array}{l}\text { Asian British pro } \\
\text { minority attitudes }\end{array}$ & $\begin{array}{l}\text { Black British pro } \\
\text { minority attitudes }\end{array}$ \\
\hline & \multicolumn{3}{|c|}{ School composition only } \\
\hline \multirow[t]{2}{*}{ School \% White British } & $-0.32 * *$ & -0.17 & $-0.23+$ \\
\hline & $(0.11)$ & $(0.11)$ & $(0.12)$ \\
\hline Personal Chars & Yes & Yes & Yes \\
\hline$R^{2}$ & 0.047 & 0.048 & 0.036 \\
\hline \multirow[t]{2}{*}{ Observations } & 2017 & 630 & 381 \\
\hline & \multicolumn{3}{|c|}{ School and neighbourhood composition } \\
\hline \multirow[t]{2}{*}{ SCH Lo|NHD Hi } & -0.01 & -0.02 & 0.11 \\
\hline & $(0.12)$ & $(0.15)$ & $(0.13)$ \\
\hline \multirow[t]{2}{*}{ SCH Hi|NHD Lo } & -0.14 & $-0.15+$ & 0.04 \\
\hline & $(0.09)$ & $(0.08)$ & $(0.17)$ \\
\hline \multirow[t]{2}{*}{ SCH Hi| NHD Hi } & $-0.16 * *$ & -0.05 & -0.13 \\
\hline & $(0.05)$ & $(0.10)$ & $(0.10)$ \\
\hline Personal Chars & Yes & Yes & Yes \\
\hline $\begin{array}{l}\text { TEST: SCH Lo|HD Hi v. } \\
\text { SCH Hi|NHD Hi }\end{array}$ & 0.19 & 0.88 & $0.10+$ \\
\hline $\mathrm{r} 2$ & 0.05 & 0.05 & 0.03 \\
\hline $\mathrm{N}$ & 2017 & 630 & 381 \\
\hline
\end{tabular}

Source: CILS4EU, UK Sample, Wave 1 \& NPD.

Notes: $\mathrm{SCH}=$ school composition of outgroup (high or low); $\mathrm{NHD}=$ neighbourhood outgroup composition (high or low). Reference category is SCH Lo NHD Lo. Notes: Test: SCH Low and NHD High $=$ SCH High and NHD High. Standard errors in parentheses. Standard errors clustered at school level. Personal characteristics comprise: sex, number of books in the home, language test score, cognitive test score. $+\mathrm{p}<0.10, * \mathrm{p}<0.05, * * \mathrm{p}<0.01 * * * \mathrm{p}<0.001$ 
Table 5: OLS regression of association of school composition with composite outgroup orientation by ethnic group, individual level with controls

\begin{tabular}{|c|c|c|c|c|c|c|c|c|}
\hline & \multicolumn{2}{|c|}{$\begin{array}{c}\text { White British orientation } \\
\text { towards Asian }\end{array}$} & \multicolumn{2}{|c|}{$\begin{array}{l}\text { White British orientation } \\
\text { towards Black }\end{array}$} & \multicolumn{2}{|c|}{$\begin{array}{l}\text { Asian British orientation } \\
\text { towards White }\end{array}$} & \multicolumn{2}{|c|}{$\begin{array}{c}\text { Black British orientation } \\
\text { towards White }\end{array}$} \\
\hline & $\begin{array}{l}\text { High } \\
\text { orientation }\end{array}$ & $\begin{array}{l}\text { Low } \\
\text { orientation }\end{array}$ & $\begin{array}{c}\text { High } \\
\text { orientation }\end{array}$ & $\begin{array}{c}\text { Low } \\
\text { orientation }\end{array}$ & $\begin{array}{c}\text { High } \\
\text { orientation }\end{array}$ & $\begin{array}{l}\text { Low } \\
\text { orientation }\end{array}$ & $\begin{array}{c}\text { High } \\
\text { orientation }\end{array}$ & $\begin{array}{l}\text { Low } \\
\text { orientation }\end{array}$ \\
\hline School \% Asian & $0.38 * * *$ & $-0.57 * * *$ & & & & & & \\
\hline British Pupils & $(0.09)$ & $(0.10)$ & & & & & & \\
\hline School \% Black & & & $0.86 * * *$ & $-0.89 * * *$ & & & & \\
\hline British Pupils & & & $(0.17)$ & $(0.16)$ & & & & \\
\hline School \% White & & & & & $0.57 * * *$ & $-0.26 * *$ & $0.56 * * *$ & $-0.18 * *$ \\
\hline British Pupils & & & & & $(0.09)$ & $(0.09)$ & $(0.08)$ & $(0.06)$ \\
\hline Personal Chars & Yes & Yes & Yes & Yes & Yes & Yes & Yes & Yes \\
\hline $\mathrm{R}^{2}$ & 0.037 & 0.044 & 0.030 & 0.024 & 0.099 & 0.037 & 0.107 & 0.021 \\
\hline Observations & 2060 & 2060 & 2060 & 2060 & 648 & 648 & 397 & 397 \\
\hline
\end{tabular}

Source: CILS4EU, UK Sample, Wave 1 \& NPD. Notes: Standard errors in parentheses. Standard errors clustered at school level. Personal characteristics comprise: sex, number of books in the home, language test score, cognitive test score.

$+\mathrm{p}<0.10, * \mathrm{p}<0.05, * * * \mathrm{p}<0.01, * * * \mathrm{p}<0.001$ 
Table 6: OLS regression of association of ethnic composition of school and local authority with net warmth towards other ethno-racial groups, by ethno-racial group, individual level with controls

\begin{tabular}{|c|c|c|c|c|c|c|}
\hline & $\begin{array}{c}\text { White British net } \\
\text { warmth for Asian } \\
\text { British }\end{array}$ & $\begin{array}{c}\text { White British net } \\
\text { warmth for Black } \\
\text { British }\end{array}$ & $\begin{array}{l}\text { Asian British net } \\
\text { warmth for White } \\
\text { British }\end{array}$ & $\begin{array}{l}\text { Black British net } \\
\text { warmth for White } \\
\text { British }\end{array}$ & $\begin{array}{c}\text { Asian British net } \\
\text { warmth for Black } \\
\text { British }\end{array}$ & $\begin{array}{c}\text { Black British net } \\
\text { warmth for Asian } \\
\text { British }\end{array}$ \\
\hline SCH Lo|NHD Hi & $\begin{array}{r}-8.04 * * \\
(2.66)\end{array}$ & $\begin{array}{r}-3.42 \\
(2.43)\end{array}$ & $\begin{array}{r}2.38 \\
(3.88)\end{array}$ & $\begin{array}{r}-2.52 \\
(7.16)\end{array}$ & $\begin{array}{r}-7.45^{*} \\
(3.48)\end{array}$ & $\begin{array}{r}1.11 \\
(5.62)\end{array}$ \\
\hline SCH Hi|NHD Lo & $\begin{array}{l}-3.60 \\
(3.76)\end{array}$ & $\begin{array}{r}-0.84 \\
(1.54)\end{array}$ & $\begin{array}{r}10.03 \\
(6.48)\end{array}$ & $\begin{array}{r}9.31 * * \\
(3.39)\end{array}$ & $\begin{array}{r}6.76 \\
(5.13)\end{array}$ & $\begin{array}{r}4.07 \\
(6.25)\end{array}$ \\
\hline SCH Hi| NHD Hi & $\begin{array}{r}-1.24 \\
(1.87)\end{array}$ & $\begin{array}{r}1.49 \\
(1.20)\end{array}$ & $\begin{array}{l}9.84^{*} \\
(4.47)\end{array}$ & $\begin{array}{l}8.85+ \\
(5.01)\end{array}$ & $\begin{array}{r}2.28 \\
(2.33)\end{array}$ & $\begin{array}{r}5.63 \\
(3.63)\end{array}$ \\
\hline $\begin{array}{l}\text { Personal } \\
\text { Characteristics }\end{array}$ & Yes & Yes & Yes & Yes & Yes & Yes \\
\hline $\begin{array}{l}\text { TEST: SCH } \\
\text { Lo|NHD Hi v. } \\
\text { SCH Hi| NHD Hi }\end{array}$ & $0.02 *$ & $0.05 *$ & 0.19 & 0.18 & $0.00 * *$ & 0.39 \\
\hline $\begin{array}{l}\mathrm{R}^{2} \\
\mathrm{~N}\end{array}$ & $\begin{array}{r}0.07 \\
1956\end{array}$ & $\begin{array}{r}0.04 \\
1956\end{array}$ & $\begin{array}{r}0.06 \\
616\end{array}$ & $\begin{array}{r}0.05 \\
370\end{array}$ & $\begin{array}{r}0.08 \\
616\end{array}$ & $\begin{array}{r}0.04 \\
370\end{array}$ \\
\hline
\end{tabular}

Source: CILS4EU, UK Sample, Wave 1 \& NPD.

Notes: $\mathrm{SCH}=$ school composition of outgroup (high or low); NHD= neighbourhood outgroup composition (high or low). Reference category is SCH Lo NHD Lo. Notes: Test: SCH Low and NHD High = SCH High and NHD High. Standard errors in parentheses. Standard errors clustered at school level. Personal characteristics comprise: sex, number of books in the home, language test score, cognitive test score.

$+\mathrm{p}<0.10, * \mathrm{p}<0.05, * * \mathrm{p}<0.01 * * * \mathrm{p}<0.001$ 
Table 7: OLS regression of association of ethnic composition of school and local authority with share of friends from other ethno-racial group, by ethno-racial group, individual level with controls

\begin{tabular}{|c|c|c|c|c|c|c|}
\hline & $\begin{array}{l}\text { Asian British } \\
\text { Friends of White } \\
\text { British }\end{array}$ & $\begin{array}{c}\text { Black British } \\
\text { Friends of White } \\
\text { British }\end{array}$ & $\begin{array}{c}\text { White British } \\
\text { Friends of Asian } \\
\text { British }\end{array}$ & $\begin{array}{c}\text { White British } \\
\text { Friends of Black } \\
\text { British }\end{array}$ & $\begin{array}{l}\text { Black British } \\
\text { Friends of Asian } \\
\text { British }\end{array}$ & $\begin{array}{c}\text { Asian British } \\
\text { Friends of Black } \\
\text { British }\end{array}$ \\
\hline SCH Lo|NHD Hi & $\begin{array}{c}0.15 \\
(0.12)\end{array}$ & $\begin{array}{l}0.30^{*} \\
(0.13)\end{array}$ & $\begin{array}{l}0.52^{*} \\
(0.25)\end{array}$ & $\begin{array}{c}0.86^{* *} \\
(0.30)\end{array}$ & $\begin{array}{l}-0.18 \\
(0.20)\end{array}$ & $\begin{array}{l}-0.17 \\
(0.19)\end{array}$ \\
\hline SCH Hi|NHD Lo & $\begin{array}{c}0.49 * * * \\
(0.10)\end{array}$ & $\begin{array}{c}0.46^{* * * *} \\
(0.11)\end{array}$ & $\begin{array}{c}1.17 * * * \\
(0.17)\end{array}$ & $\begin{array}{c}0.88^{* * * *} \\
(0.19)\end{array}$ & $\begin{array}{c}0.44 \\
(0.38)\end{array}$ & $\begin{array}{l}0.55^{*} \\
(0.22)\end{array}$ \\
\hline SCH Hi| NHD Hi & $\begin{array}{c}0.76^{* * * *} \\
(0.08)\end{array}$ & $\begin{array}{c}0.64 * * * \\
(0.10)\end{array}$ & $\begin{array}{c}1.24 * * * \\
(0.21)\end{array}$ & $\begin{array}{c}1.13 * * * \\
(0.20)\end{array}$ & $\begin{array}{c}0.74 * * * \\
(0.17)\end{array}$ & $\begin{array}{c}0.66 * * * \\
(0.14)\end{array}$ \\
\hline Personal Chars & Yes & Yes & Yes & Yes & Yes & Yes \\
\hline $\begin{array}{l}\text { TEST: SCH Lo|HD Hi } \\
\text { v. } \\
\text { SCH Hi|NHD Hi }\end{array}$ & $0.00 * *$ & $0.01 * *$ & $0.01 * *$ & 0.41 & $0.00^{* *}$ & $0.00 * *$ \\
\hline $\begin{array}{l}\mathrm{R} 2 \\
\mathrm{~N}\end{array}$ & $\begin{array}{l}0.14 \\
1952\end{array}$ & $\begin{array}{l}0.11 \\
1952\end{array}$ & $\begin{array}{c}0.14 \\
628\end{array}$ & $\begin{array}{l}0.17 \\
376\end{array}$ & $\begin{array}{c}0.14 \\
628\end{array}$ & $\begin{array}{l}0.10 \\
376\end{array}$ \\
\hline
\end{tabular}

Source: CILS4EU, UK Sample, Wave 1 \& NPD.

Notes: $\mathrm{SCH}=$ school composition of outgroup (high or low); $\mathrm{NHD}=$ neighbourhood outgroup composition (high or low). Reference category is $\mathrm{SCH}$ Lo NHD Lo. Notes: Test: SCH Low and NHD High $=$ SCH High and NHD High. Standard errors in parentheses. Standard errors clustered at school level. Personal characteristics comprise: sex, number of books in the home, language test score, cognitive test score.

$+\mathrm{p}<0.10, * \mathrm{p}<0.05, * * \mathrm{p}<0.01 * * * \mathrm{p}<0.001$ 
Table 8: OLS regression of association of ethnic composition of school and local authority with composite orientation towards other ethnic groups, by ethnic group, individual level with controls

\begin{tabular}{|c|c|c|c|c|c|c|c|c|}
\hline & \multicolumn{2}{|c|}{$\begin{array}{c}\text { White British composite } \\
\text { orientation towards Asian } \\
\text { British }\end{array}$} & \multicolumn{2}{|c|}{$\begin{array}{c}\text { White British composite } \\
\text { orientation towards Black } \\
\text { British }\end{array}$} & \multicolumn{2}{|c|}{$\begin{array}{c}\text { Asian British composite } \\
\text { orientation towards White } \\
\text { British }\end{array}$} & \multicolumn{2}{|c|}{$\begin{array}{c}\text { Black British composite } \\
\text { orientation towards White } \\
\text { British }\end{array}$} \\
\hline & $\begin{array}{c}\text { High } \\
\text { orientation }\end{array}$ & $\begin{array}{c}\text { Low } \\
\text { orientation }\end{array}$ & $\begin{array}{c}\text { High } \\
\text { orientation }\end{array}$ & $\begin{array}{c}\text { Low } \\
\text { orientation }\end{array}$ & $\begin{array}{c}\text { High } \\
\text { orientation }\end{array}$ & $\begin{array}{c}\text { Low } \\
\text { orientation }\end{array}$ & $\begin{array}{c}\text { High } \\
\text { orientation }\end{array}$ & $\begin{array}{c}\text { Low } \\
\text { orientation }\end{array}$ \\
\hline SCH Lo|NHD & 0.01 & -0.03 & 0.05 & $-0.06+$ & $0.21 *$ & -0.09 & 0.04 & 0.00 \\
\hline $\mathrm{Hi}$ & $(0.04)$ & $(0.05)$ & $(0.04)$ & $(0.03)$ & $(0.08)$ & $(0.06)$ & $(0.12)$ & $(0.08)$ \\
\hline SCH Hi|NHD & 0.03 & $-0.09 *$ & $0.12 *$ & $-0.12 * *$ & $0.16^{*}$ & -0.05 & $0.31 * * *$ & -0.04 \\
\hline Lo & $(0.04)$ & $(0.04)$ & $(0.05)$ & $(0.04)$ & $(0.08)$ & $(0.06)$ & $(0.08)$ & $(0.05)$ \\
\hline SCH Hi| NHD & $0.08 * *$ & $-0.14 * * *$ & $0.10 * *$ & $-0.12 * * *$ & $0.38 * * *$ & $-0.13 *$ & $0.37 * * *$ & -0.05 \\
\hline $\mathrm{Hi}$ & $(0.03)$ & $(0.04)$ & $(0.03)$ & $(0.03)$ & $(0.08)$ & $(0.05)$ & $(0.07)$ & $(0.06)$ \\
\hline $\begin{array}{l}\text { Personal } \\
\text { Characteristics }\end{array}$ & Yes & Yes & Yes & Yes & Yes & Yes & Yes & Yes \\
\hline $\begin{array}{l}\text { TEST: SCH } \\
\text { Lo|NHD Hi v. } \\
\text { SCH Hi| NHD } \\
\text { Hi }\end{array}$ & 0.11 & $0.04 *$ & 0.15 & $0.10+$ & $0.09+$ & 0.51 & $0.01 * *$ & 0.56 \\
\hline $\mathrm{R}^{2}$ & 0.04 & 0.05 & 0.03 & 0.03 & 0.08 & 0.02 & 0.11 & 0.03 \\
\hline $\mathrm{N}$ & 1827 & 1827 & 1827 & 1827 & 532 & 532 & 305 & 305 \\
\hline
\end{tabular}

Source: CILS4EU, UK Sample, Wave 1. Notes: SCH=school composition of outgroup (high or low); NHD= neighbourhood outgroup composition (high or low). Reference category is SCH Lo NHD Lo. Notes: Test: SCH Low and NHD High = SCH High and NHD High. Standard errors in parentheses. Standard errors clustered at school level. Personal characteristics comprise: sex, number of books in the home, language test score, cognitive test score.

$+\mathrm{p}<0.10, * \mathrm{p}<0.05, * * \mathrm{p}<0.01 * * * \mathrm{p}<0.001$ 
Table 9: Summary of Results

\begin{tabular}{|c|c|c|c|c|c|c|c|}
\hline \multirow{2}{*}{$\begin{array}{l}\text { Outcome } \\
\text { measure }\end{array}$} & \multirow[t]{2}{*}{ Level } & \multicolumn{2}{|c|}{ White British for } & \multicolumn{2}{|c|}{ White British by } & \multirow{2}{*}{$\begin{array}{l}\text { Asian British for } \\
\text { Black }\end{array}$} & \multirow{2}{*}{$\begin{array}{c}\text { Black British } \\
\text { for Asian }\end{array}$} \\
\hline & & Asian British & Black British & Asian British & Black British & & \\
\hline \multirow[t]{2}{*}{ Warmth } & $\begin{array}{l}\text { Higher levels of } \\
\text { outgroup in } \\
\text { school (Table 2) }\end{array}$ & Not significant & More warmth & More warmth & More warmth & Not significant & More warmth \\
\hline & $\begin{array}{l}\text { Neighbourhood } \\
\text { Composition } \\
\text { relative to } \\
\text { school*(Table 6) }\end{array}$ & $\begin{array}{l}\text { Negative effect of } \\
\text { neighbourhood } \\
\text { moderated by } \\
\text { school }\end{array}$ & $\begin{array}{l}\text { No significant } \\
\text { effect of } \\
\text { neighbourhood } \\
\text { but moderated } \\
\text { by school }\end{array}$ & $\begin{array}{l}\text { No significant } \\
\text { effect of } \\
\text { neighbourhood }\end{array}$ & $\begin{array}{l}\text { No significant } \\
\text { effect of } \\
\text { neighbourhood }\end{array}$ & $\begin{array}{l}\text { Negative effect of } \\
\text { neighbourhood } \\
\text { by moderated by } \\
\text { school }\end{array}$ & $\begin{array}{l}\text { No significant } \\
\text { effect of } \\
\text { neighbourhood }\end{array}$ \\
\hline \multirow[t]{2}{*}{$\begin{array}{l}\text { Friendship } \\
\text { composition }\end{array}$} & $\begin{array}{l}\text { Higher levels of } \\
\text { outgroup in } \\
\text { school (Tables } 3 \text {, } \\
\text { S4) }\end{array}$ & $\begin{array}{l}\text { More Asian } \\
\text { friends, no } \\
\text { significantly } \\
\text { higher probability } \\
\text { of out of school } \\
\text { Asian friend }\end{array}$ & $\begin{array}{l}\text { More Black } \\
\text { friends, higher } \\
\text { probability of } \\
\text { out of school } \\
\text { Black friend }\end{array}$ & $\begin{array}{l}\text { More White } \\
\text { friends, higher } \\
\text { probability of out } \\
\text { of school White } \\
\text { friend }\end{array}$ & $\begin{array}{l}\text { More White } \\
\text { friends, higher } \\
\text { probability of out } \\
\text { of school White } \\
\text { friend }\end{array}$ & $\begin{array}{l}\text { More Black } \\
\text { friends, no } \\
\text { significantly } \\
\text { higher probability } \\
\text { of out of school } \\
\text { Black friend }\end{array}$ & $\begin{array}{l}\text { More Asian } \\
\text { friends, higher } \\
\text { probability of } \\
\text { out of school }\end{array}$ \\
\hline & $\begin{array}{l}\text { Neighbourhood } \\
\text { Composition } \\
\text { relative to } \\
\text { school* (Table } \\
7 \text { ) }\end{array}$ & $\begin{array}{l}\text { No significant } \\
\text { effect of } \\
\text { neighbourhood } \\
\text { but moderated by } \\
\text { school }\end{array}$ & $\begin{array}{l}\text { Positive effect of } \\
\text { neighbourhood } \\
\text { but enhanced by } \\
\text { school }\end{array}$ & $\begin{array}{l}\text { Positive effect of } \\
\text { neighbourhood } \\
\text { but enhanced by } \\
\text { school }\end{array}$ & $\begin{array}{l}\text { Positive effect of } \\
\text { neighbourhood, no } \\
\text { significantly } \\
\text { additive effect of } \\
\text { school }\end{array}$ & $\begin{array}{l}\text { No significant } \\
\text { effect of } \\
\text { neighbourhood } \\
\text { but moderated by } \\
\text { school }\end{array}$ & $\begin{array}{l}\text { No significant } \\
\text { effect of } \\
\text { neighbourhood } \\
\text { but moderated } \\
\text { by school }\end{array}$ \\
\hline \multirow[t]{2}{*}{$\begin{array}{l}\text { Pro } \\
\text { minority } \\
\text { attitudes }\end{array}$} & $\begin{array}{l}\text { Higher levels of } \\
\text { white British in } \\
\text { school (Table 4) }\end{array}$ & Lower pro-minorit & attitudes & Not significant & $\begin{array}{l}\text { Lower (marginally } \\
\text { significant) }\end{array}$ & Not applicable & Not applicable \\
\hline & $\begin{array}{l}\text { Neighbourhood } \\
\text { Composition } \\
\text { relative to } \\
\text { school* (Table } \\
4 \text { ) }\end{array}$ & \multicolumn{2}{|c|}{$\begin{array}{l}\text { No significant effect of } \\
\text { neighbourhood; negative effect of } \\
\text { school but not significantly different } \\
\text { from neighbourhood }\end{array}$} & $\begin{array}{l}\text { No significant } \\
\text { effect of } \\
\text { neighbourhood }\end{array}$ & $\begin{array}{l}\text { No significant } \\
\text { effect of } \\
\text { neighbourhood; } \\
\text { marginally } \\
\text { significantly } \\
\text { moderated by } \\
\text { negative effect of } \\
\text { school }\end{array}$ & Not applicable & Not applicable \\
\hline
\end{tabular}




\begin{tabular}{|c|c|c|c|c|c|c|c|}
\hline \multirow[t]{2}{*}{$\begin{array}{l}\text { High / Low } \\
\text { Composite }\end{array}$} & $\begin{array}{l}\text { Higher levels of } \\
\text { outgroup in } \\
\text { school (Table 5) }\end{array}$ & \multirow{2}{*}{$\begin{array}{l}\text { Higher high and } \\
\text { lower low } \\
\text { orientations } \\
\text { No significant } \\
\text { effect partly } \\
\text { moderated by } \\
\text { school effect }\end{array}$} & \multirow{2}{*}{$\begin{array}{l}\text { Higher high and } \\
\text { lower low } \\
\text { orientations } \\
\text { No significant/ } \\
\text { negative effect } \\
\text { partly moderated } \\
\text { by school effect }\end{array}$} & \multirow{2}{*}{$\begin{array}{l}\text { Higher high and } \\
\text { lower low } \\
\text { orientations } \\
\text { Positive / no } \\
\text { significant effect } \\
\text { partly enhanced } \\
\text { by school effect }\end{array}$} & \multirow{2}{*}{$\begin{array}{l}\text { Higher high and } \\
\text { lower low } \\
\text { orientations } \\
\text { No significant } \\
\text { effect partly } \\
\text { moderated by } \\
\text { school effect }\end{array}$} & \multirow{2}{*}{$\begin{array}{l}\text { Not applicable } \\
\text { Not applicable }\end{array}$} & \multirow{2}{*}{$\begin{array}{l}\text { Not applicable } \\
\text { Not applicable }\end{array}$} \\
\hline & $\begin{array}{l}\text { Neighbourhood } \\
\text { Composition } \\
\text { relative to } \\
\text { school* (Table } \\
8)\end{array}$ & & & & & & \\
\hline
\end{tabular}

*Here we summarise both whether there is any significant effect of living in a high neighbourhood concentration relative to a low neighbourhood concentration and whether that effect is different if there is also a high school concentration. 


\section{Inter-ethnic relations: Supplementary materials}

\section{Figures}

Figure S1: Comparison of school composition measured by NPD and as reported by CILS4EU sample
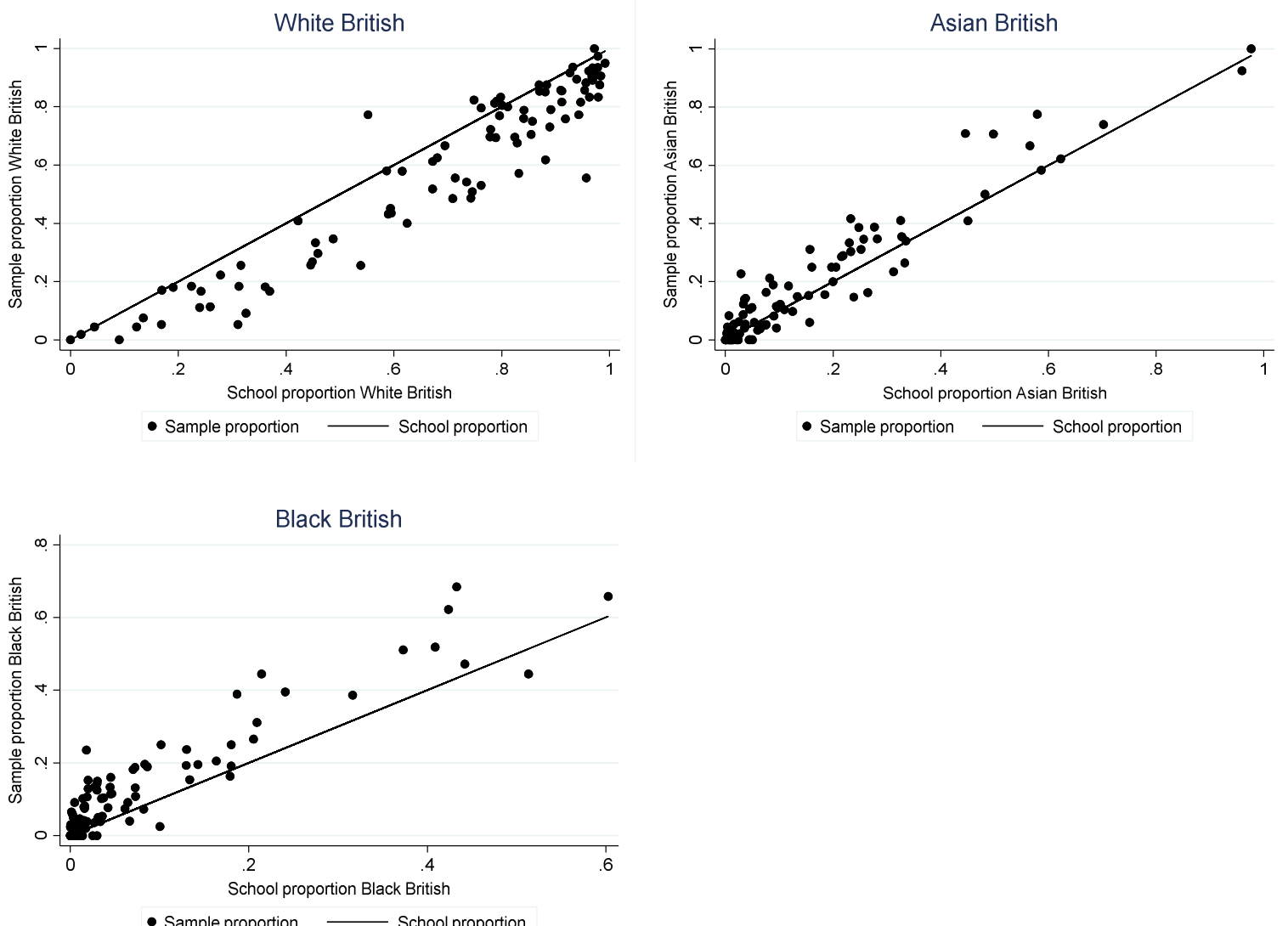
Figure S2: LOWESS of net warmth for outgroup by ethnic composition of school, by ethnic group, school level, full distribution

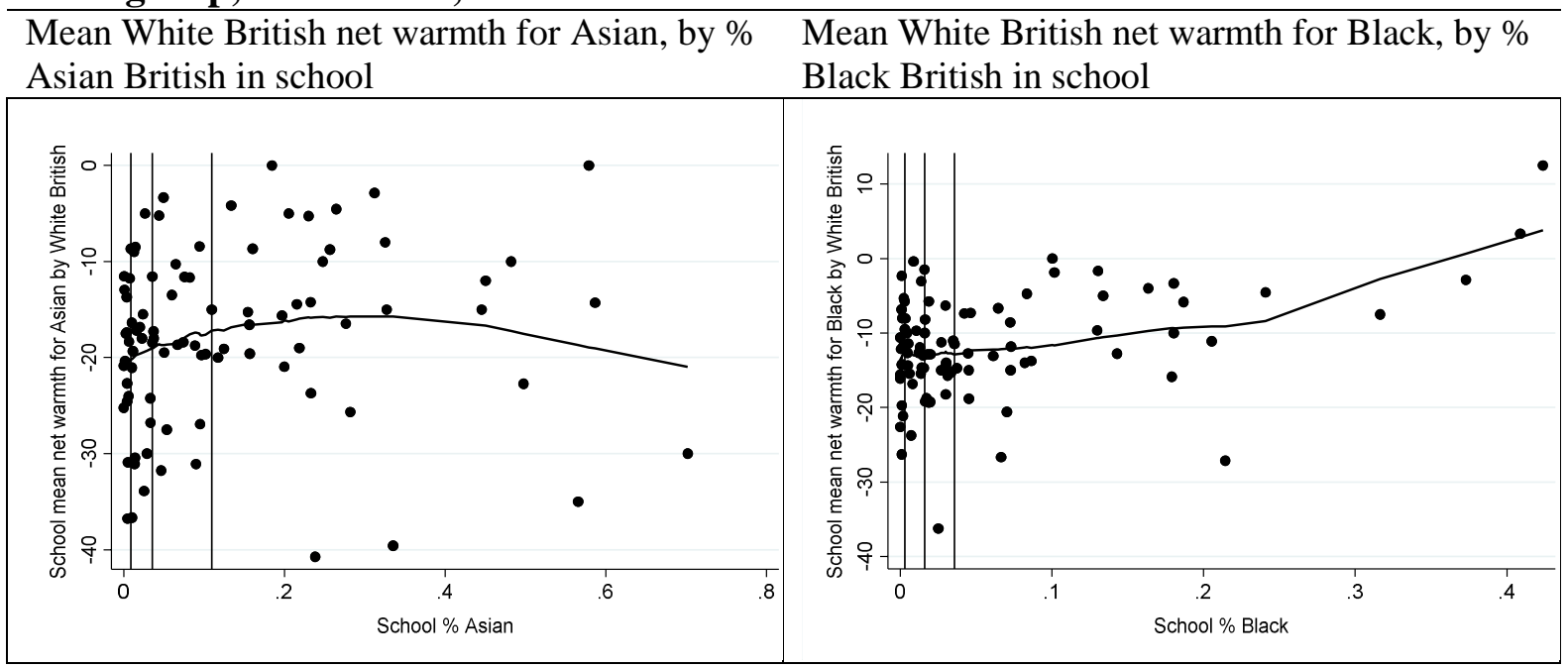

Mean Asian British net warmth for White, by \% Mean Black British net warmth for White, by \% White British in school White British in school
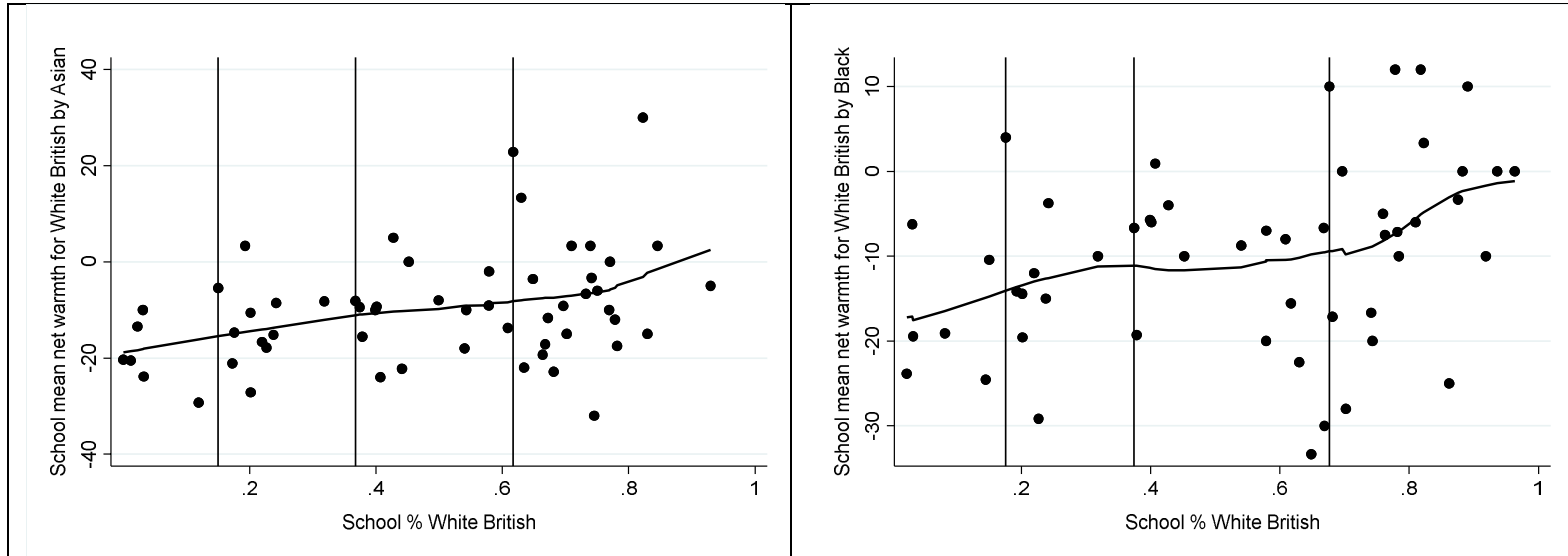

Mean Asian British net warmth for Black, by \% Black British in school

Mean Black British net warmth for Asian, by \%

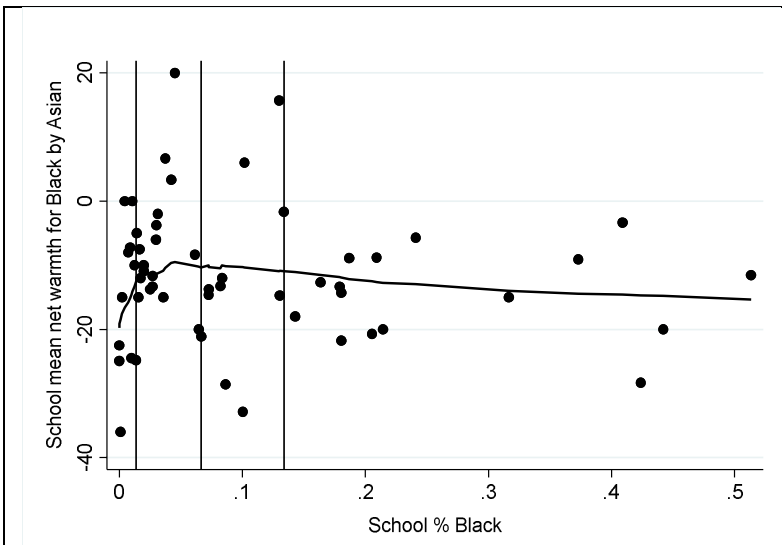
Asian British in school

Source: CILS4EU, UK Sample, Wave 1 \& NPD. Note: black vertical lines at lower and upper quartiles and median of sample school composition of outgroup as experienced by individuals from each group. 
Figure S3: LOWESS of proportion of 5 'best friends' from outgroup, by ethnic composition of school, by ethnic group, school level

Mean proportion of 5 friends of White British Mean proportion of 5 friends of White British who are Asian, by \% Asian British in school who are Black, by \% Black British in school
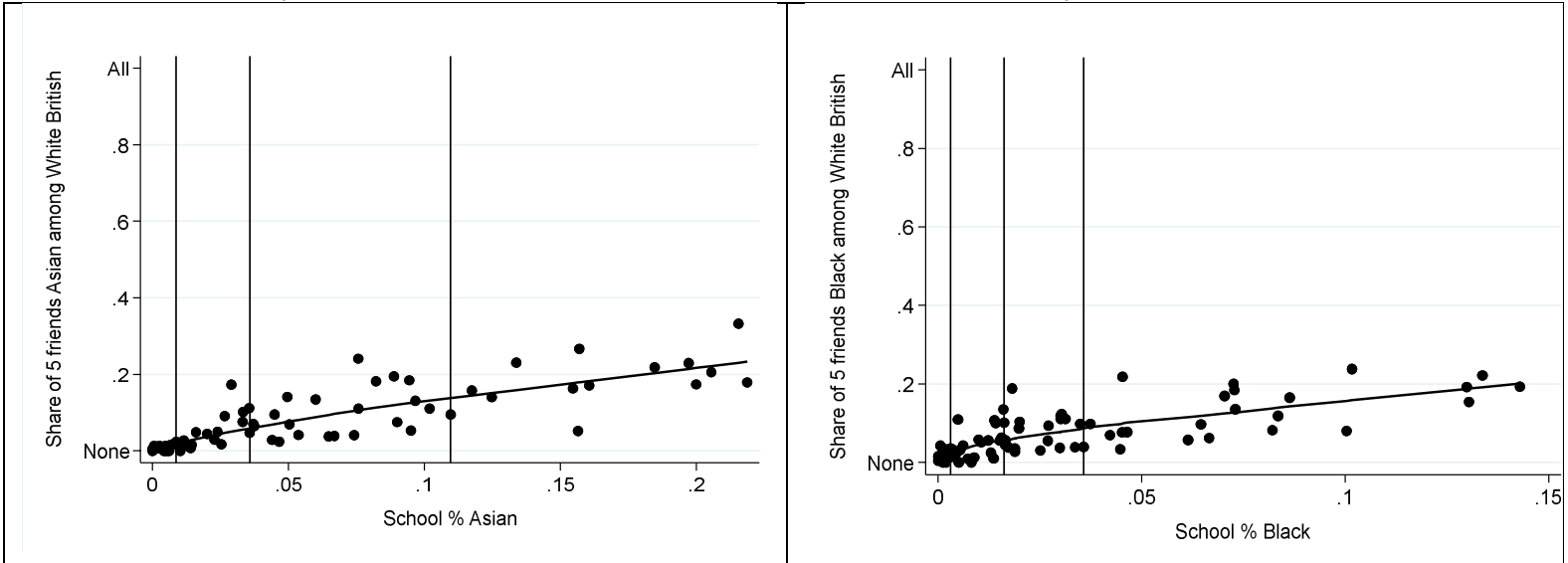

Mean proportion of friends of Asian British who are White, by \% White British in school

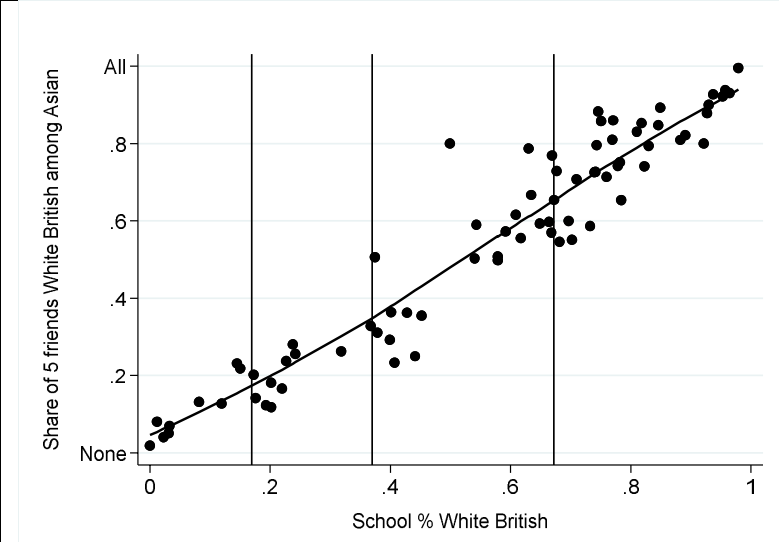

Mean proportion of 5 friends of Asian British who are Black, by \% Black British in school who are White, by \% White British in school

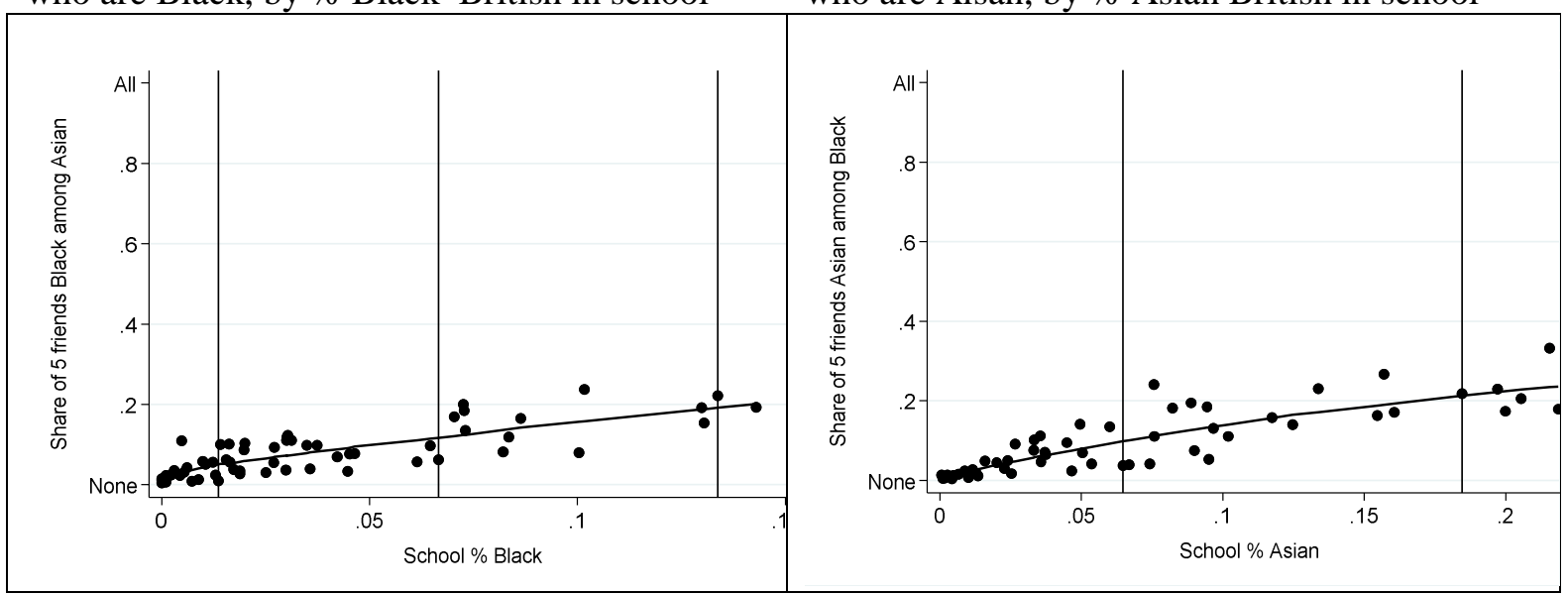

Source: CILS4EU, UK Sample, Wave 1 \& NPD. Note: black vertical lines at lower and upper quartiles and median of sample school composition of outgroup as experienced by individuals from each group. For clarity, distribution shown up to the $90^{\text {th }}$ percentile of the national school distribution. Figures with full distribution available on request. 


\section{Tables}

Table S1: Descriptives of outcome measures by ethno-racial group: warmth for own/ other groups, composition of friendships, and pro minority attitudes

\begin{tabular}{|c|c|c|c|}
\hline & $\begin{array}{l}\text {...among White } \\
\text { British }\end{array}$ & $\begin{array}{l}\text {...among Asian } \\
\text { British }\end{array}$ & $\begin{array}{l}\text {...among Black } \\
\text { British }\end{array}$ \\
\hline \multicolumn{4}{|l|}{ A) Warmth } \\
\hline \multicolumn{4}{|l|}{$\begin{array}{l}\text { on scale of 1-100, } \\
\text { mean }(S D), \text { for: }\end{array}$} \\
\hline White British & $88.2(17.0)$ & $69.7(24.6)$ & $70.6(25.8)$ \\
\hline Asian British & $69.4(27.7)$ & $81.8(20.7)$ & $66.5(28.3)$ \\
\hline $\begin{array}{l}\text { Black British } \\
\text { net of own group for: }\end{array}$ & $76.3(24.0)$ & $67.6(25.6)$ & $83.2(19.0)$ \\
\hline White British & 0 & $-12.0(24.8)$ & $-12.5(25.6)$ \\
\hline Asian British & $-18.8(27.3)$ & 0 & $-16.6(26.0)$ \\
\hline Black British & $-11.9(21.5)$ & $-14.2(25.2)$ & 0 \\
\hline $\mathrm{N}$ & 1956 & 616 & 370 \\
\hline \multicolumn{4}{|l|}{ B) $\begin{array}{l}\text { Friendship } \\
\text { composition }\end{array}$} \\
\hline \multicolumn{4}{|l|}{$\begin{array}{l}\text { Scale from } 1 \text { (none or } \\
\text { very few) to } 5 \text { (all or } \\
\text { almost all): Mean } \\
(S D)\end{array}$} \\
\hline White British friends & $4.37(0.74)$ & $2.72(1.16)$ & $3.06(1.17)$ \\
\hline Asian British friends & $1.76(0.90)$ & $3.89(1.11)$ & $2.45(1.07)$ \\
\hline Black British friends & $2.05(0.95)$ & $2.20(1.05$ & $3.65(1.16)$ \\
\hline Black British friends & 1.9 & 2.2 & 24.4 \\
\hline $\mathrm{N}$ & 1878 & 614 & 363 \\
\hline \multicolumn{4}{|l|}{$\begin{array}{l}\text { Proportion of } 5 \\
\text { selected friends, mean } \\
\text { (SD), who are: }\end{array}$} \\
\hline White British & $0.85(0.22)$ & $0.20(0.28)$ & $0.31(0.33)$ \\
\hline Asian British & $0.05(0.11)$ & $0.64(0.35)$ & $0.13(0.19)$ \\
\hline Black British & $0.06(0.12)$ & $0.09(0.17)$ & $0.41(0.33)$ \\
\hline $\mathrm{N}$ & 1977 & 633 & 383 \\
\hline \multicolumn{4}{|l|}{$\begin{array}{l}\text { Probability of having } \\
\text { a friend who is not in } \\
\text { school, mean ( } S D) \text {, } \\
\text { who is: }\end{array}$} \\
\hline White British & $0.42(0.49)$ & $0.12(0.32)$ & $0.22(0.42)$ \\
\hline Asian British & $0.02(013)$ & $0.31(0.46)$ & $0.04(0.21)$ \\
\hline Black British & $0.04(019)$ & $0.06(0.23)$ & $0.35(0.48)$ \\
\hline $\mathrm{N}$ & 1977 & 633 & 383 \\
\hline \multicolumn{4}{|l|}{$\begin{array}{l}\text { C) Pro minority } \\
\text { attitudes } \\
\text { on scale of } 1-5 \text { (higher } \\
=\text { stronger agreement) }\end{array}$} \\
\hline Mean (SD) & $3.4(0.8)$ & $3.7(0.8)$ & $3.8(0.8)$ \\
\hline $\mathrm{N}$ & 1852 & 555 & 310 \\
\hline
\end{tabular}

Source: CILS4EU, UK Sample, Wave 1. 
Table S2: Descriptive statistics of explanatory measures by ethno-racial group, percent / mean (SD)

\begin{tabular}{|c|c|c|c|c|}
\hline & $\begin{array}{l}\text { White } \\
\text { British }\end{array}$ & $\begin{array}{l}\text { Asian } \\
\text { British }\end{array}$ & $\begin{array}{l}\text { Black } \\
\text { British }\end{array}$ & Total \\
\hline Boys & 52.5 & 55.2 & 41.9 & 51.7 \\
\hline $\begin{array}{l}\text { Books in the home: } \\
\text { scale from } 1(0-25) \text { to } 5(500+)\end{array}$ & $2.5(1.2)$ & $2.1(1.1)$ & $2.2(1.1)$ & $2.4(1.2)$ \\
\hline $\begin{array}{l}\text { Cognitive ability (sumscore from test), } \\
\text { range }=0-15\end{array}$ & $11.4(2.2)$ & $11.4(2.3)$ & $10.8(2.4)$ & $11.4(2.3)$ \\
\hline $\begin{array}{l}\text { Language ability (sumscore from test), } \\
\text { range }=8-24\end{array}$ & $17.2(2.8)$ & $16.6(3.2)$ & $16.4(3.1)$ & $17.0(2.9)$ \\
\hline School share White British & $0.77(0.19)$ & $0.37(0.26)$ & $0.43(0.28)$ & $0.64(0.29)$ \\
\hline School share Asian British & $0.09(0.12)$ & $0.41(0.29)$ & $0.20(0.16)$ & $0.17(0.22)$ \\
\hline School share Black British & $0.04(0.06)$ & $0.10(0.12)$ & $0.19(0.16)$ & $0.07(0.11)$ \\
\hline Neighbourhood share White British & $0.81(0.16)$ & $0.60(0.21)$ & $0.54(0.25)$ & $0.73(0.22)$ \\
\hline Neighbourhood share Asian British & $0.07(0.08)$ & $0.18(0.11)$ & $0.15(0.11)$ & $0.11(0.10)$ \\
\hline Neighbourhood share Black British & $0.04(0.06)$ & $0.09(0.09)$ & $0.15(0.13)$ & $0.06(0.09)$ \\
\hline $\mathrm{N}$ & 1956 & 616 & 370 & 2942 \\
\hline
\end{tabular}

Source: CILS4EU, UK Sample, Wave 1. All descriptives show the mean (SD) except for Boys, which shows the percentage of the sample who are boys. 
Table S3a: Ordered logit regression of association between school composition and share of friends from other ethno-racial groups by ethno-racial group, individual level with controls

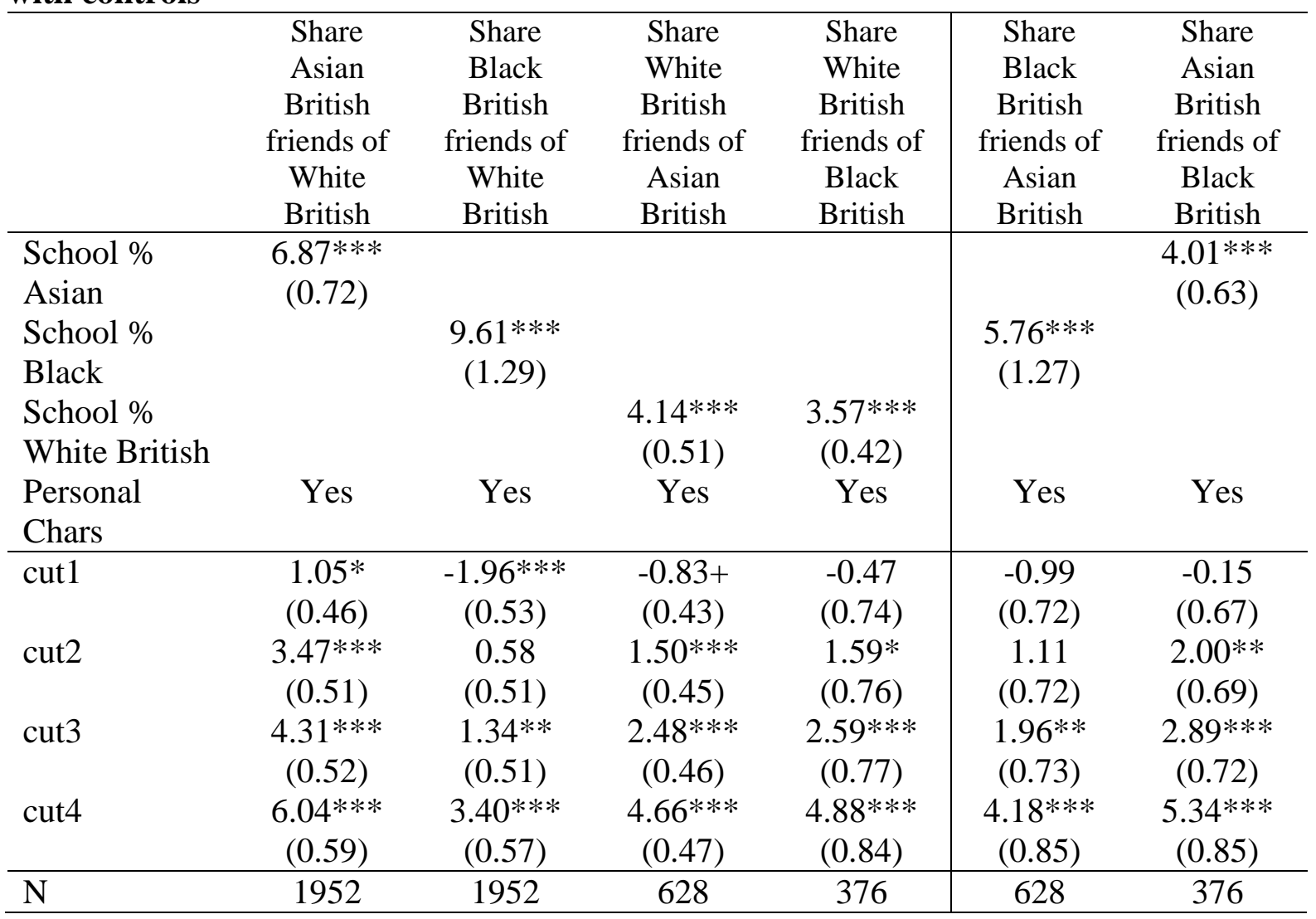

Source: CILS4EU, UK Sample, Wave 1 \& NPD. Notes: Standard errors in parentheses. Standard errors clustered at school level. Personal characteristics comprise: sex, number of books in the home, language test score, cognitive test score.

$+\mathrm{p}<0.10, * \mathrm{p}<0.05, * * \mathrm{p}<0.01, * * * \mathrm{p}<0.001$ 
Table S3b: OLS regression of association between school composition and proportion of 5 friends from other ethno-racial groups by ethno-racial group, individual level with controls

\begin{tabular}{|c|c|c|c|c|c|c|}
\hline & $\begin{array}{c}\text { Proportion } \\
\text { of } 5 \text { friends } \\
\text { of White } \\
\text { British } \\
\text { who are } \\
\text { Asian } \\
\text { British }\end{array}$ & $\begin{array}{c}\text { Proportion } \\
\text { of } 5 \text { friends } \\
\text { of White } \\
\text { British } \\
\text { who are } \\
\text { Black } \\
\text { British }\end{array}$ & $\begin{array}{c}\text { Proportion } \\
\text { of } 5 \text { friends } \\
\text { of Asian } \\
\text { British } \\
\text { who are } \\
\text { White } \\
\text { British }\end{array}$ & $\begin{array}{c}\text { Proportion } \\
\text { of } 5 \text { friends } \\
\text { of Black } \\
\text { British } \\
\text { who are } \\
\text { White } \\
\text { British }\end{array}$ & $\begin{array}{c}\text { Proportion } \\
\text { of } 5 \text { friends } \\
\text { of Asian } \\
\text { British } \\
\text { who are } \\
\text { Black } \\
\text { British }\end{array}$ & $\begin{array}{c}\text { Proportion } \\
\text { of } 5 \text { friends } \\
\text { of Black } \\
\text { British } \\
\text { who are } \\
\text { Asian } \\
\text { British }\end{array}$ \\
\hline School \% & $0.31 * * *$ & & & & & $0.43 * * *$ \\
\hline Asian & $(0.05)$ & & & & & $(0.12)$ \\
\hline School \% & & $0.63 * * *$ & & & $0.43 * * *$ & \\
\hline Black & & $(0.08)$ & & & $(0.11)$ & \\
\hline School \% & & & $0.55 * * *$ & $0.69 * * *$ & & \\
\hline White British & & & $(0.05)$ & $(0.05)$ & & \\
\hline $\begin{array}{l}\text { Personal } \\
\text { Chars }\end{array}$ & Yes & Yes & Yes & Yes & Yes & Yes \\
\hline$R^{2}$ & 0.125 & 0.107 & 0.323 & 0.391 & 0.086 & 0.124 \\
\hline Observations & 1977 & 1977 & 633 & 383 & 633 & 383 \\
\hline
\end{tabular}

Source: CILS4EU, UK Sample, Wave 1 \& NPD. Notes: Standard errors in parentheses. Standard errors clustered at school level. Personal characteristics comprise: sex, number of books in the home, language test score, cognitive test score.

$+\mathrm{p}<0.10, * \mathrm{p}<0.05, * * \mathrm{p}<0.01, * * * \mathrm{p}<0.001$ 
Table S3c: Logit regression of association between school composition and probability of one of 5 best friends being an out of school friend from another ethno-racial group, by ethno-racial group, individual level with controls

\begin{tabular}{|c|c|c|c|c|c|c|}
\hline & $\begin{array}{c}\text { White } \\
\text { British } \\
\text { with Asian } \\
\text { out of } \\
\text { school } \\
\text { friend }\end{array}$ & $\begin{array}{c}\text { White } \\
\text { British } \\
\text { with Black } \\
\text { out of } \\
\text { school } \\
\text { friend }\end{array}$ & $\begin{array}{c}\text { Asian } \\
\text { British } \\
\text { with } \\
\text { White out } \\
\text { of school } \\
\text { friend }\end{array}$ & $\begin{array}{c}\text { Black } \\
\text { British } \\
\text { with } \\
\text { White out } \\
\text { of school } \\
\text { friend }\end{array}$ & $\begin{array}{c}\text { Asian } \\
\text { British } \\
\text { with } \\
\text { Black out } \\
\text { of school } \\
\text { friend }\end{array}$ & $\begin{array}{c}\text { Black } \\
\text { British } \\
\text { with } \\
\text { Asian out } \\
\text { of school } \\
\text { friend }\end{array}$ \\
\hline $\begin{array}{l}\text { School \% } \\
\text { Asian } \\
\text { School \% } \\
\text { Black } \\
\text { School \% } \\
\text { White }\end{array}$ & $\begin{array}{c}-0.56 \\
(1.20)\end{array}$ & $\begin{array}{c}4.70 * * * \\
(1.09)\end{array}$ & $\begin{array}{l}1.54 * * \\
(0.49)\end{array}$ & $\begin{array}{l}1.57 * * \\
(0.52)\end{array}$ & $\begin{array}{c}1.29 \\
(1.19)\end{array}$ & $\begin{array}{l}2.29 * \\
(0.96)\end{array}$ \\
\hline $\begin{array}{l}\text { British } \\
\text { Personal } \\
\text { Chars }\end{array}$ & Yes & Yes & Yes & Yes & Yes & Yes \\
\hline Observations & 1977 & 1977 & 633 & 383 & 633 & 383 \\
\hline
\end{tabular}

Source: CILS4EU, UK Sample, Wave 1 \& NPD. Notes: Standard errors in parentheses. Standard errors clustered at school level. Personal characteristics comprise: sex, number of books in the home, language test score, cognitive test score.

$+\mathrm{p}<0.10, * \mathrm{p}<0.05, * * \mathrm{p}<0.01, * * * \mathrm{p}<0.001$

Table S4d: Logit regression of association between school composition and probability of meeting any of five best friends from another ethno-racial group out of school, by ethno-racial group, individual level with controls

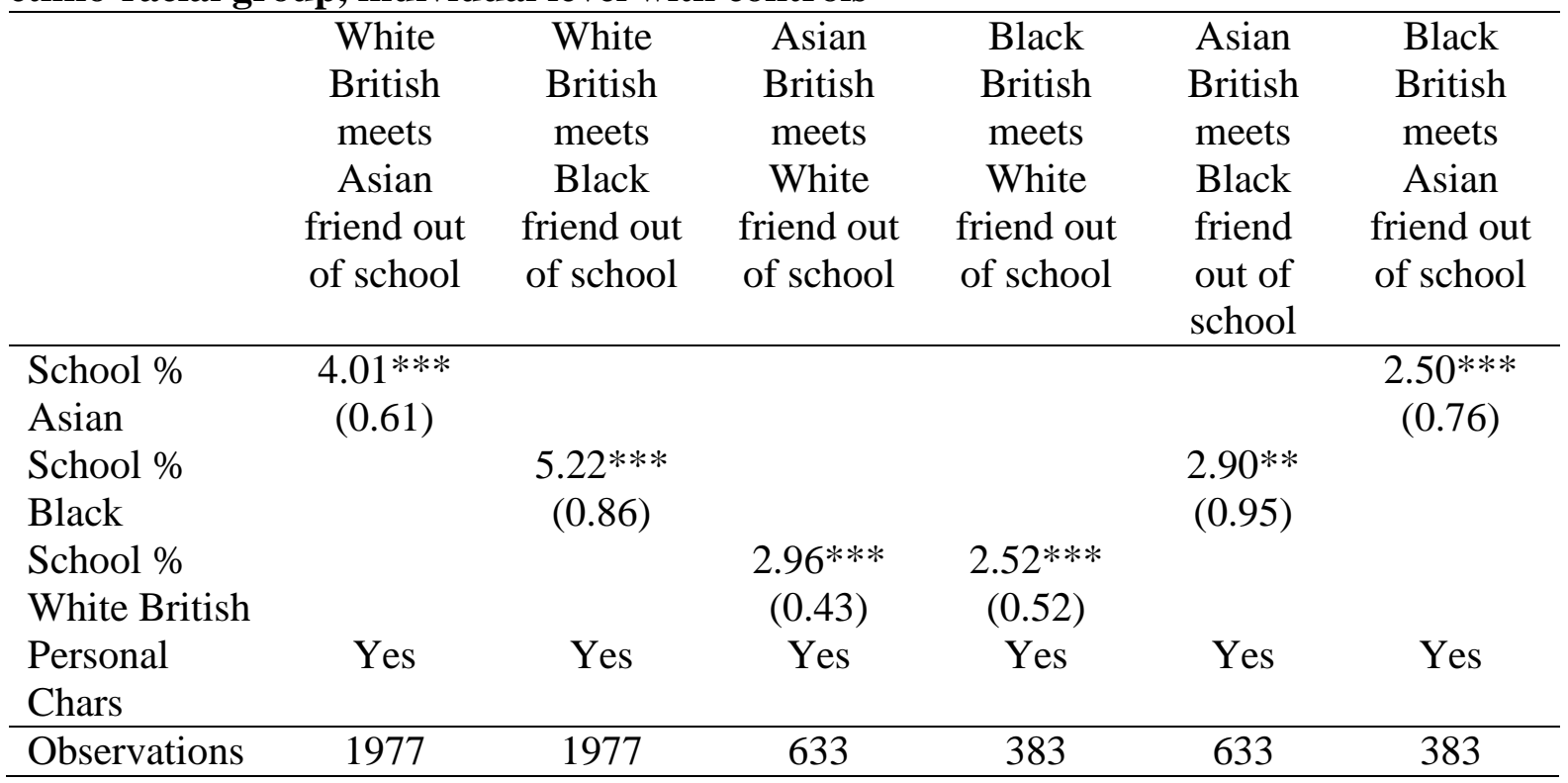

Source: CILS4EU, UK Sample, Wave 1 \& NPD. Notes: Standard errors in parentheses. Standard errors clustered at school level. Personal characteristics comprise: sex, number of books in the home, language test score, cognitive test score.

$+\mathrm{p}<0.10, * \mathrm{p}<0.05, * * \mathrm{p}<0.01, * * * \mathrm{p}<0.001$ 
Table S5: OLS regression of association of ethnic composition of school and local authority with proportion 5 best friends from other ethno-racial group, by ethno-racial group, individual level with controls

\begin{tabular}{|c|c|c|c|c|c|c|}
\hline & $\begin{array}{l}\text { (1) } \\
\text { Asian British } \\
\text { Friends of White } \\
\text { British }\end{array}$ & $\begin{array}{c}\text { Black British } \\
\text { Friends of White } \\
\text { British }\end{array}$ & $\begin{array}{c}\text { (3) } \\
\text { White British } \\
\text { Friends of Asian } \\
\text { British } \\
\end{array}$ & $\begin{array}{c}\text { (4) } \\
\text { White British } \\
\text { Friends of Black } \\
\text { British } \\
\end{array}$ & $\begin{array}{c}\text { (5) } \\
\text { Black British } \\
\text { Friends of Asian } \\
\text { British }\end{array}$ & $\begin{array}{c}\text { (6) } \\
\text { Asian British } \\
\text { Friends of Black } \\
\text { British }\end{array}$ \\
\hline SCH Lo|NHD Hi & $\begin{array}{c}0.01 \\
(0.01)\end{array}$ & $\begin{array}{c}0.01 \\
(0.01)\end{array}$ & $\begin{array}{l}0.17^{*} \\
(0.06)\end{array}$ & $\begin{array}{c}0.27 * * \\
(0.10)\end{array}$ & $\begin{array}{c}0.00 \\
(0.02)\end{array}$ & $\begin{array}{c}0.03 \\
(0.03)\end{array}$ \\
\hline SCH Hi|NHD Lo & $\begin{array}{l}0.02^{*} \\
(0.01)\end{array}$ & $\begin{array}{l}0.03^{*} \\
(0.01)\end{array}$ & $\begin{array}{l}0.28 * * \\
(0.09)\end{array}$ & $\begin{array}{c}0.35 * * * \\
(0.07)\end{array}$ & $\begin{array}{c}0.06^{* *} \\
(0.02)\end{array}$ & $\begin{array}{c}0.03 \\
(0.04)\end{array}$ \\
\hline SCH Hi| NHD Hi & $\begin{array}{c}0.08 * * * \\
(0.01)\end{array}$ & $\begin{array}{c}0.06^{* * * *} \\
(0.01)\end{array}$ & $\begin{array}{c}0.44 * * * \\
(0.06)\end{array}$ & $\begin{array}{c}0.45 * * * \\
(0.06)\end{array}$ & $\begin{array}{c}0.09 * * * \\
(0.02)\end{array}$ & $\begin{array}{l}0.10 * * \\
(0.03)\end{array}$ \\
\hline Personal Chars & Yes & Yes & Yes & Yes & Yes & Yes \\
\hline $\begin{array}{l}\text { TEST: SCH Lo|HD Hi } \\
\text { v. } \\
\text { SCH Hi|NHD Hi }\end{array}$ & $0.00 * *$ & $0.00 * *$ & $0.00 * *$ & $0.10+$ & $0.00 * *$ & $0.06+$ \\
\hline $\begin{array}{l}\mathrm{R} 2 \\
\mathrm{~N}\end{array}$ & $\begin{array}{l}0.12 \\
1977\end{array}$ & $\begin{array}{l}0.06 \\
1977\end{array}$ & $\begin{array}{c}0.24 \\
633\end{array}$ & $\begin{array}{c}0.32 \\
383\end{array}$ & $\begin{array}{l}0.07 \\
633\end{array}$ & $\begin{array}{l}0.04 \\
383\end{array}$ \\
\hline
\end{tabular}

Source: CILS4EU, UK Sample, Wave 1 \& NPD.

Notes: $\mathrm{SCH}=$ school composition of outgroup (high or low); $\mathrm{NHD}=$ neighbourhood outgroup composition (high or low). Reference category is SCH Lo NHD Lo. Notes: Test: SCH Low and NHD High $=$ SCH High and NHD High. Standard errors in parentheses. Standard errors clustered at school level. Personal characteristics comprise: sex, number of books in the home, language test score, cognitive test score.

$+\mathrm{p}<0.10, * \mathrm{p}<0.05, * * \mathrm{p}<0.01 * * * \mathrm{p}<0.001$ 
Table S6: Logit of the association between school and neighbourhood composition with probability of having out-of-school outgroup friend, by ethno-racial group, individual level with controls

\begin{tabular}{|c|c|c|c|c|c|c|}
\hline & $\begin{array}{c}\text { Asian British } \\
\text { Friends of White } \\
\text { British }\end{array}$ & $\begin{array}{c}\text { Black British } \\
\text { Friends of White } \\
\text { British }\end{array}$ & $\begin{array}{c}\text { White British } \\
\text { Friends of Asian } \\
\text { British }\end{array}$ & $\begin{array}{c}\text { White British } \\
\text { Friends of Black } \\
\text { British }\end{array}$ & $\begin{array}{c}\text { Black British } \\
\text { Friends of Asian } \\
\text { British }\end{array}$ & $\begin{array}{c}\text { Asian British } \\
\text { Friends of Black } \\
\text { British }\end{array}$ \\
\hline SCH Lo|NHD Hi & $\begin{array}{c}0.63 \\
(0.38)\end{array}$ & $\begin{array}{l}0.73+ \\
(0.43)\end{array}$ & $\begin{array}{c}0.51 \\
(0.57)\end{array}$ & $\begin{array}{c}1.63 * * * \\
(0.37)\end{array}$ & $\begin{array}{c}0.85 \\
(0.63)\end{array}$ & $\begin{array}{c}0.81 \\
(0.91)\end{array}$ \\
\hline SCH Hi|NHD Lo & $\begin{array}{l}-0.39 \\
(1.02)\end{array}$ & $\begin{array}{l}1.55 * * * \\
(0.41)\end{array}$ & $\begin{array}{l}-0.13 \\
(0.80)\end{array}$ & $\begin{array}{c}0.50 \\
(0.53)\end{array}$ & $\begin{array}{l}1.45 * \\
(0.63)\end{array}$ & $\begin{array}{l}0.00 \\
(.)^{\mathrm{a}}\end{array}$ \\
\hline SCH Hi| NHD Hi & $\begin{array}{c}0.19 \\
(0.39)\end{array}$ & $\begin{array}{c}1.25 * * * \\
(0.34)\end{array}$ & $\begin{array}{l}1.20 * * \\
(0.42)\end{array}$ & $\begin{array}{c}0.50 \\
(0.40)\end{array}$ & $\begin{array}{c}0.80 \\
(0.49)\end{array}$ & $\begin{array}{c}1.11 \\
(0.78)\end{array}$ \\
\hline Personal Chars & Yes & Yes & Yes & Yes & Yes & Yes \\
\hline $\begin{array}{l}\text { TEST: SCH Lo|HD Hi v. } \\
\text { SCH Hi|NHD Hi }\end{array}$ & 0.28 & 0.13 & 0.30 & $0.01 * *$ & 0.93 & 0.68 \\
\hline $\mathrm{N}$ & 1977 & 1977 & 633 & 383 & 633 & 368 \\
\hline
\end{tabular}

Source: CILS4EU, UK Sample, Wave 1 \& NPD.

Notes: $\mathrm{SCH}=$ school composition of outgroup (high or low); NHD= neighbourhood outgroup composition (high or low). Reference category is SCH Lo NHD

Lo. Notes: Test: SCH Low and NHD High = SCH High and NHD High. Standard errors in parentheses. Standard errors clustered at school level. Personal characteristics comprise: sex, number of books in the home, language test score, cognitive test score. ${ }^{\mathrm{a}}$ Due to the relatively rare occurrences, within a small overall sample, there were no cases of an outgroup out of school friend for this school-neighbourhood combination.

$+\mathrm{p}<0.10, * \mathrm{p}<0.05, * * \mathrm{p}<0.01 * * * \mathrm{p}<0.001$ 
Table S7: Splitting the estimation by school academic quality

$\begin{array}{cccc}\text { Net Warmth of } & \text { Net Warmth of } & \text { Net Warmth of } & \text { Net Warmth of } \\ \text { White British } & \text { White British } & \text { Asian British } & \text { Black British } \\ \text { for Asian British } & \text { for Black British } & \text { for White } & \text { for White } \\ & & \text { British } & \text { British }\end{array}$

\begin{tabular}{lcccc}
\hline \multicolumn{4}{c}{ Panel A: All schools, replicating the main panel of Table 2 } \\
\hline School \% Asian & -2.69 & & \\
& $(7.28)$ & $17.87^{*}$ & & \\
School \% Black & & $(7.07)$ & $14.23^{* * *}$ & $13.58^{* *}$ \\
& & & $(4.07)$ & $(4.97)$ \\
School \% White & & Yes & Yes & Yes \\
British & Yes & 0.04 & 0.06 & 0.05 \\
Personal Chars & 0.06 & 1964 & 619 & 374 \\
\hline R2 & 1959 & & & \\
N & & & & \\
\hline
\end{tabular}

Panel B: Only schools in the top half of local academic quality ranking

\begin{tabular}{lcccc}
\hline School \% Asian & $\begin{array}{c}-5.37 \\
(12.95)\end{array}$ & & & \\
School \% Black & & $20.55^{*}$ & & \\
& & $(8.63)$ & & \\
School \% White & & & $13.96^{*}$ & 7.41 \\
British & & & $(5.61)$ & $(7.28)$ \\
Personal Chars & Yes & Yes & Yes & Yes \\
\hline R2 & 0.07 & 0.05 & 0.05 & 0.08 \\
N & 1091 & 1096 & 280 & 174 \\
\hline
\end{tabular}

Source: CILS4EU, UK Sample, Wave $1 \&$ NPD. Notes: Standard errors in parentheses. Standard errors clustered at school level. Personal characteristics comprise: sex, number of books in the home, language test score, cognitive test score.

$+\mathrm{p}<0.10, * \mathrm{p}<0.05, * * \mathrm{p}<0.01 * * * \mathrm{p}<0.001$ 


\section{Note: The construction of the composite measure of warmth, friendships and attitudes.}

Our measure is intended to maintain a straightforward and transparent connection to the underlying responses on our three key indicators of warmth, friendships at attitudes. By splitting into low and high composite measures, we not only increase the illustrative potential of the measure, we can lessen the influence of noise in the measure. We therefore define two binary variables, labelled as high orientations and low orientations, which are not exhaustive categories (most people are neither). To illustrate: a White British pupil is accorded a 'high orientation' towards Asian British if they satisfy two of the following conditions:

o Feelings: warmth of feeling for Asians is in the upper quartile

o Friends: you report the fraction of your friends who are Asian is: half, a lot, or all

o Attitudes: you report agreement with the (combined) pro-minority attitudinal questions

We say you have a 'low orientation' if you satisfy two of these three conditions:

o Feelings: your warmth of feeling for Asians is in the lower quartile

o Friends: you report the fraction of your friends who are Asian is none/ almost none

o Attitudes: you report disagreement with the (combined) pro-minority attitudinal questions

For Asian British and Black British orientations to White British pupils, we disagreement with prominority attitudes for high orientation and agreement for low orientation. 